Article

\title{
Expanding the Chemical Space of Benzimidazole Dicationic Ionic Liquids
}

\author{
Andrea Mezzetta ${ }^{1, *(\mathbb{D})}$, Luca Guglielmero ${ }^{1,2}$, Angelica Mero ${ }^{1}$, Giorgio Tofani ${ }^{1,3}{ }^{\mathbb{C}}$, Felicia $\mathrm{D}^{\prime}$ Andrea ${ }^{1}$, \\ Christian Silvio Pomelli ${ }^{1}$ (D) and Lorenzo Guazzelli ${ }^{1}$ (D) \\ 1 Department of Pharmacy, University of Pisa, Via Bonanno 33, 56126 Pisa, Italy; \\ luca.guglielmero@phd.unipi.it (L.G.); angelica.mero@phd.unipi.it (A.M.); giorgio.tofani@df.unipi.it (G.T.); \\ felicia.dandrea@farm.unipi.it (F.D.); christian.pomelli@unipi.it (C.S.P.); lorenzo.guazzelli@unipi.it (L.G.) \\ 2 DESTEC, University of Pisa, Largo Lucio Lazzarino, 56122 Pisa, Italy \\ 3 Department of Physics, University of Pisa, Largo Bruno Pontecorvo 3, 56127 Pisa, Italy \\ * Correspondence: andrea.mezzetta@unipi.it
}

check for updates

Citation: Mezzetta, A.; Guglielmero, L.; Mero, A.; Tofani, G.; D’Andrea, F.; Pomelli, C.S.; Guazzelli, L. Expanding the Chemical Space of Benzimidazole Dicationic Ionic Liquids. Molecules 2021, 26, 4211. https://doi.org/ $10.3390 /$ molecules 26144211

Academic Editor: Paula Berton

Received: 18 June 2021

Accepted: 9 July 2021

Published: 11 July 2021

Publisher's Note: MDPI stays neutral with regard to jurisdictional claims in published maps and institutional affiliations.

Copyright: (c) 2021 by the authors. Licensee MDPI, Basel, Switzerland. This article is an open access article distributed under the terms and conditions of the Creative Commons Attribution (CC BY) license (https:/ / creativecommons.org/licenses/by/ $4.0 /)$.

\begin{abstract}
Benzimidazole dicationic ionic liquids (BDILs) have not yet been widely explored in spite of their potential. Therefore, two structurally related families of BDILs, paired with either bromide or bistriflimide anions and bearing alkyl spacers ranging from $\mathrm{C} 3$ to $\mathrm{C} 6$, have been prepared. Their thermal properties have been studied by thermogravimetric analysis (TGA) and differential scanning calorimetry (DSC), while their electrical properties have been assessed by cyclic voltammetry (CV). TG analysis confirmed the higher stability of the bistriflimide BDILs over the bromide BDILs, with minor variation within the two families. Conversely, DSC and CV allowed for ascertaining the role played by the spacer length. In particular, the thermal behavior changed dramatically among the members of the bistriflimide family, and all three possible thermal behavior types of ILs were observed. Furthermore, cyclic voltammetry showed different electrochemical window $\left(\mathrm{C}_{3}\left(\mathrm{C}_{1} \text { BenzIm }\right)_{2} / 2 \mathrm{Tf}_{2} \mathrm{~N}\right.$ $\left.<\mathrm{C}_{4}\left(\mathrm{C}_{1} \text { BenzIm }\right)_{2} / 2 \mathrm{Tf}_{2} \mathrm{~N}, \mathrm{C}_{5}\left(\mathrm{C}_{1} \text { BenzIm }\right)_{2} / 2 \mathrm{Tf}_{2} \mathrm{~N}<\mathrm{C}_{6}\left(\mathrm{C}_{1} \text { BenzIm }\right)_{2} / 2 \mathrm{Tf}_{2} \mathrm{~N}\right)$ as well as a reduction peak potential, shape, and intensity as a function of the spacer length. The results obtained highlight the benefit of accessing a more structurally diverse pool of compounds offered by dicationic ILs when compared to the parent monocationic ILs. In particular, gains are to be found in the ease of fine-tuning their properties, which translates in facilitating further investigations toward BDILs as designer solvents and catalysts.
\end{abstract}

Keywords: ionic liquids; green solvents; benzimidazole; dicationic ionic liquids; thermal stability; thermal behavior; cyclic voltammetry

\section{Introduction}

In the last 20 years, ionic liquids (ILs) have been undoubtedly a "hot" topic in the field of sustainable chemistry [1]. The number of ILs studied has grown constantly, and their use has spread in all branches of science, from chemistry [2] and engineering [3] to biology and medicine [4]. The reason for this sustained interest in ILs lies in their structural variability, which makes it possible to design suitable matching ions for a given application [5]. Although ILs exhibit unique properties and potential such as unmatched ability to dissolve several biopolymers [6,7], high thermal stability [8,9], high ability to solubilize gas [10], and high refractive index [11], the reputation of ILs as "green" solvents is certainly ascribable to their negligible vapor pressure, which makes them safe when compared to traditional organic solvents [12,13]. In fact, ILs are practically non-flammable [14], and the possibility of accidental spills is negligible. However, the environmental footprint and toxicity of ILs have been analyzed over time under different perspectives leading to a re-evaluation of the effective, sustainable nature of at least some of these media. To improve ILs' sustainabilityrelated issues, synthetic procedures for their preparation have been optimized, focusing on the replacement or elimination of polluting organic solvents and on the usage of 
reagents deriving from renewable sources [15]. In parallel to this approach, toxicity and biodegradation assessments pointed to structural elements of the cationic and anionic parts capable of ameliorating the overall impact profile of ILs $[16,17]$ This new type of ILs, often referred to as the fourth generation of ILs, allowed for expanding the portfolio of possible applications in the fields of food science [18,19], medicine [20,21] and pharmaceutics [22,23].

On the other hand, the development of new structures, the exploration of the intertwining interactions between cation and anion, and the understanding of the relationship between the structure and the physico-chemical properties of the solvent are with no doubt other heavily studied areas in the field of ILs. In this context, dicationic ionic liquids (DILs) allowed for a broadening of the structural variability of ILs. DILs are composed of two cations connected by a suitable linker and paired with two counteranions [24]. Although linear spacers are the most commonly found in literature, linkers of different nature have also been reported, such as branched alkyl [25], polyethers [26], aromatic chains [27-29], and fragments derived from natural sources [30]. Compared to the parent monocationic ILs, DILs exhibit superior tunability and present different structural organizations [31]. These peculiar features often result in lower polarity, higher thermal stability [28,32], higher glass transition temperatures and melting points [33-35], larger surface tensions, higher shear viscosities [36], and lower ecotoxicity when compared to monocationic ILs [37]. These properties allowed DILs to be used effectively in a wider portfolio of applications, including catalysis [38,39], high-temperature batteries [40], high-temperature lubricants [41], stationary phases for chromatography [42], and dye-sensitized solar cells [43].

In addition to the structural modifications of specific ions, the search for new cations is key for the fine-tuning of ILs properties. In this framework, benzimidazolium-based ILs (BILs) have been certainly understudied with respect to the vast majority of cations described in literature, such as imidazolium, pyridinium, pyrrolidinium, and morpholinium [44]. Starting from the first report by Katritzky et al. [45], BILs were investigated in fields that comprise $\mathrm{CO}_{2}$ capture and conversion [46,47], electronics [48-50], dye solar cells [51], anticancer and antibacterial agents [52,53], bioremediation technologies [54,55], fuel desulfurization [56], extraction [57], lignin conversion [58], and fuel cell [59,60]. On the other hand, an area in which BILs were heavily studied is organic synthesis, where they were successfully used as catalysts in several reaction classes such as the Biginelli reaction [61], the Micheal reaction [62,63], condensations [64-67], alkylations [68], amine formylation [69], coupling [70], and esterifications [71]. Furthermore, the use of BILs as catalysts has also been reported in the preparation of natural-derived building blocks: in the transesterification of castor oil with methanol [72], in the production of ethyl levulinate [73] and in the preparation of 5-hydroxymethyl furfural starting from chitosan [74].

The benzimidazole nucleus has also been used for the preparation of benzimidazole dicationic ionic liquids (BDILs). Similar to what was mentioned above, the use of dicationic structures allows for increasing the modulation ability of the BILs. Although the number of reported papers is limited, BDILs have been employed in a large number of fields such as in analytics [75], metal extractions [76], as chelating agents [77], pharmaceutics [78] and surfactants $[79,80]$. One of the first applications of BDILs was against microbial agents, both neat $[81,82]$ and coated on multiwalled carbon nanotube [52]. In the pharmaceutical field, Clark et al. [83] reported the effective use of magnetic BDILs in DNA extraction for analytical purposes. In addition, for BDILs, the majority of the attention has been paid by the organic chemistry community, with an emphasis on their role as reaction catalysts. BDILs have been used in many transformations spanning from Heck [84], Suzuki [85], Benzoin [86], and Kumada couplings [87] to desulfurization reactions [88], and esterifications [89]. Furthermore, by treating a DBIL with a strong base, a cyclic "dimer" can be formed, which is highly reactive toward air and can be used as an organic super-electron donor [90]. In the case of the imidazole dicationic ILs, the reaction is less favorable, and it is necessary to start from a cyclic dicationic species with a more demanding synthesis [91]. These compounds have been used as single and double electron transfer systems in organic reactions [92,93] and as initiators for radical polymerizations [94]. 
Despite the promising potential shown by DBILs, they are still underexplored with respect to their imidazole analogs. This holds true both in terms of their practical applications and of their physico-chemical properties, and their changes as a function of the chemical structure. For the above reasons, in the present work, we report the study of the thermal and electrical properties of two structurally related series of BDILs with bromide and bis(trifluoromethane)sulfonimide as anions.

\section{Results and Discussion}

\subsection{Synthesis of Benzimidazole Dicationic Ionic Liquids}

A series of structurally related dibromides benzimidazole dicationic ionic liquids (1-4), varying in the length of the alkyl spacer between the cationic headgroups from $\mathrm{C} 3$ to $\mathrm{C} 6$, was synthesized via the Menschutkin reaction between $\mathrm{N}$-methylbenzimidazole and different dibromoalkane (Scheme 1). Starting from the dibromide precursors, $\mathrm{C}_{\mathrm{n}}(\mathrm{BenzIm})_{2} / 2 \mathrm{Tf}_{2} \mathrm{~N} \mathrm{5-8}$ were then prepared through metathesis reaction using lithium bis(trifluoromethane)sulfonimide (Scheme 1).

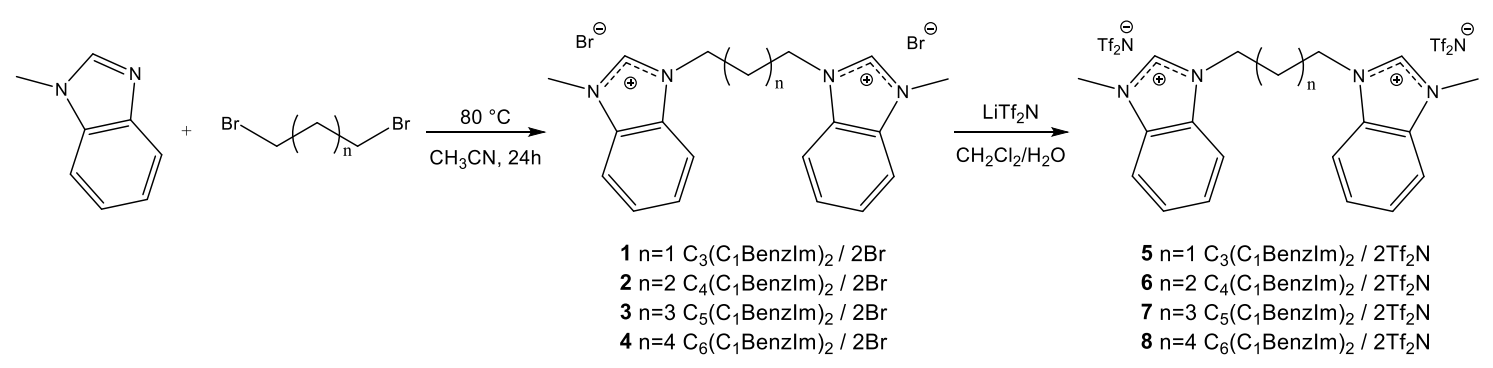

Scheme 1. Synthetic procedure for the synthesis of benzimidazole dicationic ionic liquids 1-8.

The chemical structures of benzimidazolium salts (1-8) were assessed by NMR experiments $\left({ }^{1} \mathrm{H}\right.$ and $\left.{ }^{13} \mathrm{C}\right)$, and all spectral data were in accordance with the proposed structures. For bis(trifluoromethane)sulfonimide BDILs the complete anion exchange and removal of the halide anion were evaluated by means of the silver nitrate test. In the ${ }^{13} \mathrm{C}$ NMR spectrum of compounds 5-8, the presence of the quadruplet signal (around $121 \mathrm{ppm}, J_{\mathrm{C}, \mathrm{F}}$ about $320 \mathrm{~Hz}$ ), ascribable to the $\mathrm{CF}_{3}$ group, confirmed the presence of the bis(trifluoromethane)sulfonimide anion. It is worth noting that in the ${ }^{1} \mathrm{H}$ spectra of compounds 1-8, the signal of the $\mathrm{H}-2$ (NCHN, 9.69-9.29) attributable to benzimidazolium core decreases as a function of time (see Supplementary Information, Figures S7 and S11). This phenomenon is due to the fact that the $\mathrm{H}-2$ of the imidazolium ring exchanges with the deuterium of the solvent if a protic solvent is used as $\mathrm{CD}_{3} \mathrm{OD}$ in the present case $[95,96]$. The ${ }^{13} \mathrm{C}$ NMR spectra confirmed the presence of the deuterium at the carbon $\mathrm{C}-2$, giving a triplet around 143 ppm (J about 33.5-32.5 Hz) (see Supplementary Information, S14).

\subsection{Thermal Gravimetric Analysis (TGA)}

The thermal stability of all synthesized BDILs was studied by thermal gravimetric analysis. All samples were accurately dried before the analysis and subjected to a further drying cycle consisting of an isothermal run at $60^{\circ} \mathrm{C}$ for $30 \mathrm{~min}$. The BDILs were exposed to a linear increase in temperature $\left(10^{\circ} \mathrm{C} / \mathrm{min}\right)$ up to $700{ }^{\circ} \mathrm{C}$, and the mass loss was recorded. Three typical thermal stability parameters $T_{\text {start }}, T_{\text {onset, }}$ and $T_{\text {peak }}$ were obtained from the thermograms for each investigated BDIL. The data registered are reported in Figure 1 and Table S1. A comparison between the curves obtained for bromide based-BDILs (1-4) and bistriflimide based-BDILs (5-8) is shown in Figure 2. The single TG and DTG curves of each compound are reported in the Supplementary Information (Figures S23-S30). 


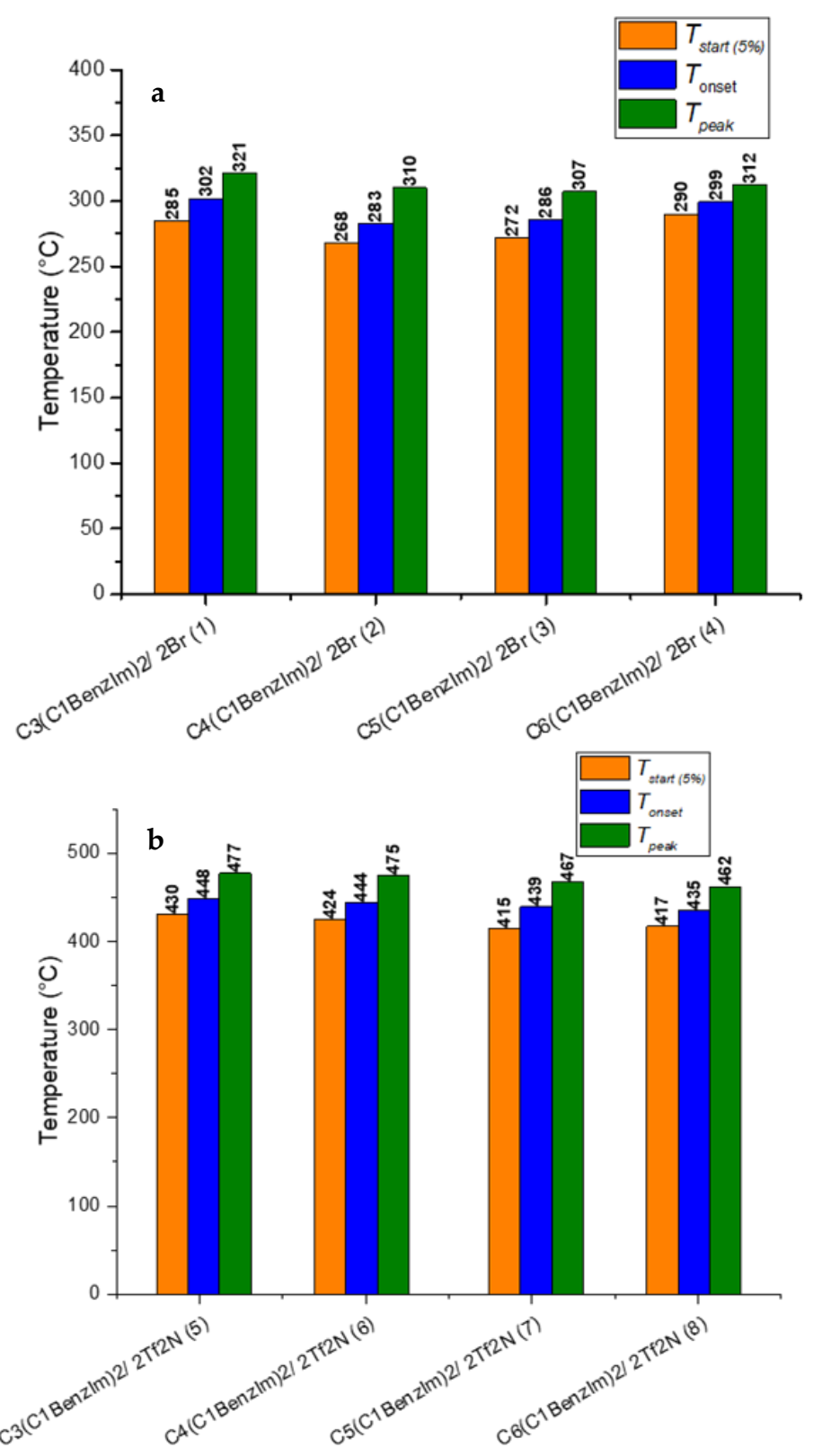

Figure 1. $T_{\text {start }}, T_{\text {onset, }}$ and $T_{\text {peak }}$ for the bromide (a) and the bistriflimide (b) BDILs at a heating rate of $10^{\circ} \mathrm{C} / \mathrm{min}$.
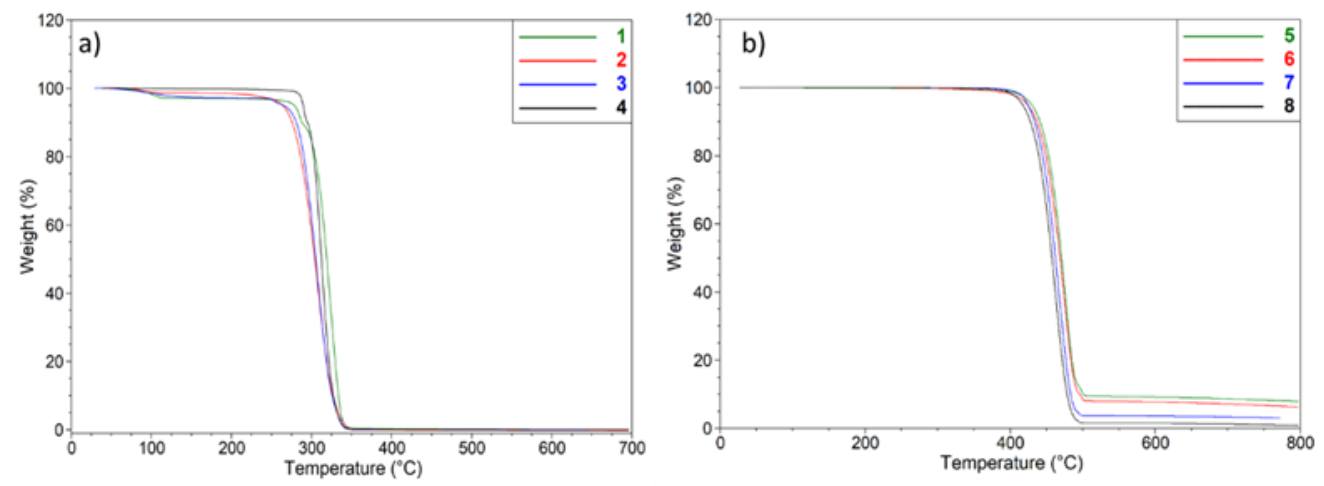

Figure 2. Thermal gravimetric analysis of bromide (a) and $\mathrm{Tf}_{2} \mathrm{~N}$ BDILs (b). 
All $\mathrm{Tf}_{2} \mathrm{~N}$ BDILs were characterized mainly by one degradation process with decomposition temperatures that slightly decreased as the length of the linker increased. In this context, Kermanioryani et al. studied the physico-chemical properties of novel imidazolium-based ILs, among which the monocationic butyl-benzimidazolium bistriflimide $[\mathrm{BzBIm}] \mathrm{Tf} \mathrm{f}_{2} \mathrm{~N}$. The authors reported a $T_{\text {onset }}$ of $421.52{ }^{\circ} \mathrm{C}$ for this latter IL, a lower value if compared to the corresponding dicationic BDILs with a $\mathrm{C}_{4}$ linker (6) synthesized in this work. This suggests higher thermal stability for dicationic benzimidazolium ILs with respect to the monocationic ones [97]. Furthermore, a comparison with $\mathrm{Tf}_{2} \mathrm{~N}$ imidazolium dicationic ILs, previously synthesized by our group, allows for interesting considerations [35]. All samples were thermally characterized using the same instrument and analysis conditions employed in this work. It was observed that all the $\mathrm{Tf}_{2} \mathrm{~N}$ imidazolium dicationic ILs with linkers of different lengths (C3 or $\mathrm{C} 6)$ bearing different lateral substituents (C4 or C8) showed higher thermal stability ( $T_{\text {onset }}$ ranging between $467^{\circ} \mathrm{C}$ and $478^{\circ} \mathrm{C}$ ) than the $\mathrm{Tf}_{2} \mathrm{~N}$ BDILs proposed here. A similar trend was reported by Al-Mohammed et al., who synthesized and characterized bis-imidazolium and benzimidazolium gemini-type ILs containing the sulphamide moiety in the linker and six different lateral chains [82]. Indeed, they observed that imidazolium DILs, with chloride and bromide anions, generally displayed higher thermal stability than ILs with benzimidazolium cations.

On the other hand, all bromide BDILs thermograms presented the main degradation step with a small shoulder at the beginning of the process. Moreover, the bromide salts $\mathbf{2}$ and 3 displayed a lower $T_{\text {start }}$ than $\mathbf{1}$ and $\mathbf{4}$ due to the mass loss below $100^{\circ} \mathrm{C}$, which is ascribable to the evaporation of the absorbed and bounded water. Indeed, despite the accurate drying process before the analysis, bromide BDILs are difficult to dry due to their hygroscopic character. When the bromide BDILs were compared to the bromide methylimidazolium dicationic ILs, also synthesized by our group with the same alkyl linker lengths (from C3 to C6), they did not show substantial differences regarding the thermal stability. Indeed, the methylimidazolium DILs displayed $T_{\text {onset }}$ ranging from 282 to $298^{\circ} \mathrm{C}$ [98].

Following the thermal stability classification based on the $T_{\text {onset }}$ values of 66 different ILs described by $\mathrm{Cao}$ and $\mathrm{Mu}$, who identified five possible stability levels [99], the bromide BDILs 1-4 belong to the "less stable" class $\left(250{ }^{\circ} \mathrm{C}<T_{\text {onset }}<300{ }^{\circ} \mathrm{C}\right)$ while the $\mathrm{Tf}_{2} \mathrm{~N}$ BDILs 5-8 belong to the "most stable" class $\left(400^{\circ} \mathrm{C}<\mathrm{T}_{\text {onset }}<450^{\circ} \mathrm{C}\right)$.

\subsection{Differential Scanning Calorimetry (DSC)}

The thermal behavior of all synthesized BDILs was explored by differential scanning calorimetry analyses performed at different scanning rates $\left(2-20^{\circ} \mathrm{C} / \mathrm{min}\right)$ under nitrogen atmosphere and in the temperature range going from -90 to $200{ }^{\circ} \mathrm{C}$. In particular, for bromide BDILs a first heating run was registered at $10^{\circ} \mathrm{C} / \mathrm{min}$, and the melting of the hydrated form was clearly observed with the exclusion of compound 4 (Table S2). Next, all samples were subjected to the second cycle of cooling-heating at $10{ }^{\circ} \mathrm{C} / \mathrm{min}$. All the thermograms of bromides BDILs 1-4 are reported in the Supplementary file (S31-34, Table S3). Compound 4 did not show any transition, suggesting a degradation step before melting. Compounds $\mathbf{1}$ and $\mathbf{3}$ displayed only the melting of the hydrated form during the first heating run, while they did not show any transition in the second cycle. Finally, compound 2 presented both the melting of the hydrated form and of the anhydrous form in the first heating run, while it showed only a glass transition at $73{ }^{\circ} \mathrm{C}$ in the second cycle. It is worth noting how the corresponding dicationic methylimidazolium bromides ILs showed a more complex thermal behavior, generally characterized by a glass transition or a solid-solid transition, a cold crystallization, and a melting process during the heating run [98]. For what concern the $\mathrm{Tf}_{2} \mathrm{~N}$ based-BDILs, after the second cycle at $10^{\circ} \mathrm{C} / \mathrm{min}$, the third cycle of cooling-heating at $5{ }^{\circ} \mathrm{C} / \mathrm{min}$ was registered. Compound 7 was also subjected to three additional cooling-heating cycles at 15,20 , and $2{ }^{\circ} \mathrm{C} / \mathrm{min}$ to investigate in-depth its thermal behavior. The second cycle of all the $\mathrm{Tf}_{2} \mathrm{~N}$ BDILs is reported in Figure 3 , while 
the other thermograms, including the comparison between the different scanning rates, are reported in the Supplementary Information (S35-S38).
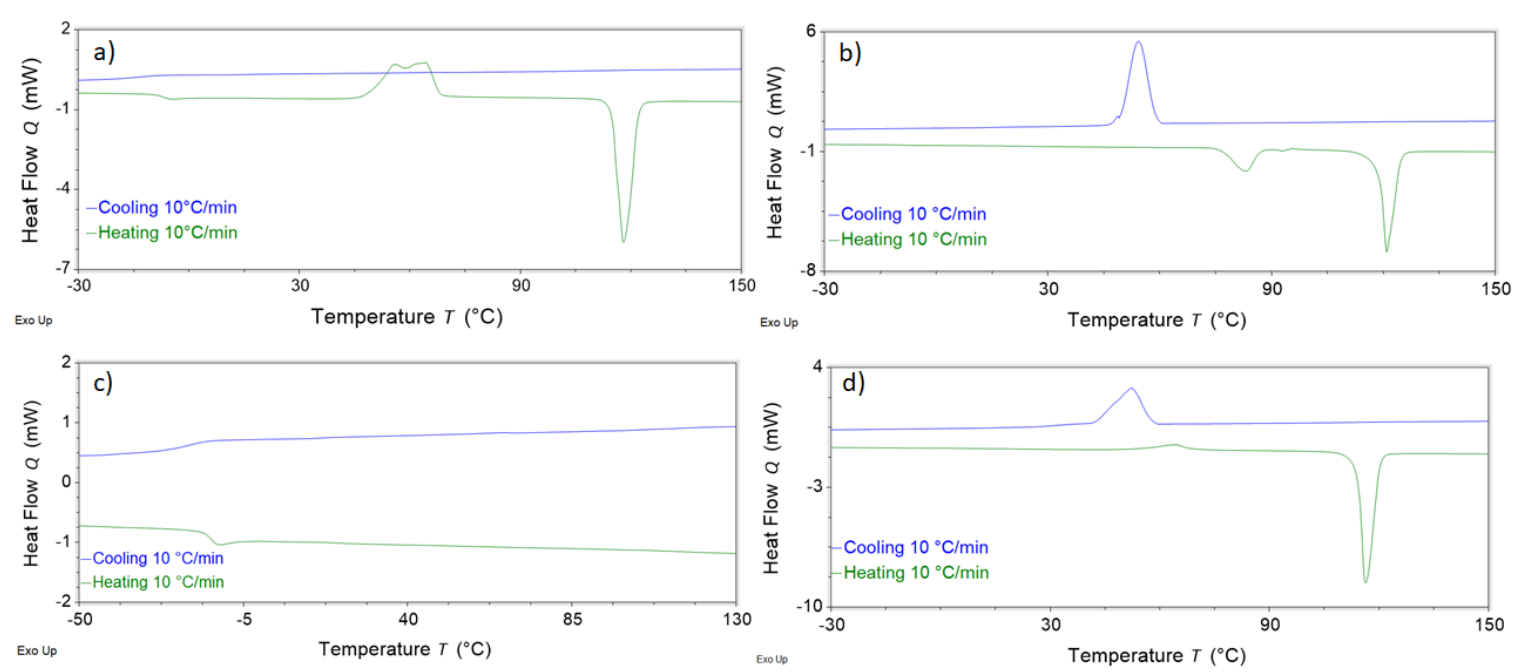

Figure 3. Differential scanning calorimetry (DSC) of compounds 5 (a), 6 (b), 7 (c), and 8 (d).

Gómez et al. [100] reported three thermal behaviors usually observed for ILs: (i) salts, which display only a glass transition (type I); (ii) ILs behaving as common salt showing the melting transition upon heating and the corresponding freezing transition upon cooling (type II); and (iii) ILs that do not show a tendency to crystallize upon cooling, which, however, display a cold crystallization on heating (type III). For the investigated $\mathrm{Tf}_{2} \mathrm{~N}$ BDILs whose only difference is the length of the linker between the benzimidazolium heads, all three thermal behaviors were found. Indeed, as can be observed from Figure 3, BDILs $\mathbf{6}$ and $\mathbf{8}$ behave as type II ILs. More specifically, $\mathbf{6}$ presented two melting phenomena $\left(83^{\circ} \mathrm{C}\right.$ and $121^{\circ} \mathrm{C}$ ) during the heating run and a single crystallization upon the cooling run at all tested heating rates. Similarly, 8 was characterized by melting and related freezing transitions. A small cold crystallization was also visible on both the heating runs registered at $10{ }^{\circ} \mathrm{C} / \mathrm{min}$ and at $5{ }^{\circ} \mathrm{C} / \mathrm{min}$. Compound 5 displayed, instead, a typical type III thermal behavior. Indeed, it did not exhibit the formation of crystals during the cooling run corresponding to the melting transition, but a cold crystallization was clearly observed following a glass transition in the heating run. This behavior was noticed at all different heating rates. Finally, BDIL 7, after exhibiting a melting transition at $88^{\circ} \mathrm{C}$ during the first heating at $10^{\circ} \mathrm{C} / \mathrm{min}$, showed only a glass transition at all the different scanning rates examined $\left(2,5,10,15\right.$ and $\left.20^{\circ} \mathrm{C} / \mathrm{min}\right)$ without any other phase transition, thus indicating a type I behavior. More precisely, the first run showed melting of the sample obtained as a solid from its preparation by adding an antisolvent to the reaction mixture. Instead, when the melted sample was slowly cooled to $-90{ }^{\circ} \mathrm{C}$, it did not exhibit the formation of a crystalline form in the cooling run while a glass transition appeared in the subsequent heating run. It is interesting to note how decreasing the scanning rate from 20 to $2{ }^{\circ} \mathrm{C} / \mathrm{min}$ caused the $T_{\mathrm{g}}$ values to slightly increase (from -17.6 to $-13.9{ }^{\circ} \mathrm{C}$, respectively). As a result of this behavior, it was possible to determine BDIL $7^{\prime}$ s apparent activation energy $\left(E_{\mathrm{a}}\right)$ for the relaxation times controlling the structural enthalpy relaxation and consequently its fragility index $(m)$, an important parameter correlated to the conductivity of an IL [101]. It is known that studying the variation of $T_{\mathrm{g}}$ as a function of the heating rate $(\beta)$ allows for an estimation of $E_{\mathrm{a}}$ and thus the $m$ parameter. Therefore, in the Supplementary file, the 
logarithm of the heating rate $(\ln \beta)$ has been plotted as a function of $1 / \mathrm{T}$. A linear trend was obtained, and $E_{\mathrm{a}}$ and $m$ were determined (Table S4) through the following equations:

$$
\begin{gathered}
\frac{d \ln \beta}{\frac{d 1}{T_{g}}}=-\frac{E_{a}}{R} \\
m=\frac{1}{2.303}\left[\frac{E_{a}\left(T_{g}\right)}{R T_{g}}\right]
\end{gathered}
$$

Compared to the corresponding dicationic $\mathrm{C}_{5}\left(\mathrm{C}_{1} \mathrm{Im}\right)_{2} / 2 \mathrm{Tf}_{2} \mathrm{~N}$ studied by Sippel et al. [102] and to other $\mathrm{Tf}_{2} \mathrm{~N}$ dicationic imidazolium ILs with different alkyl chain length on the imidazole ring reported previously by our group [35], BDIL 7 displays higher $T_{\mathrm{g}}$ and lower $m$ values. Consequently, it could be assumed that this BDIL will show lower conductivity than the corresponding imidazolium system. Indeed, the highest conductivities were obtained for ILs characterized by both a high fragility index and a low $T_{\mathrm{g}}$.

Lastly, the already reported influence of the temperature scanning rate on the thermal behavior of an IL [103] was observed here: higher rates caused the glass transition and cold crystallization temperatures to increase while the freezing temperature was reduced. Instead, the melting transition was not influenced by the different scanning rates.

The data obtained from the thermal analyses allowed the assessment of the operative range of these new BDILs, as shown in Figure 4 . The $T_{\text {onset }}$ of melting transition, gathered from DSC analyses, was taken as the minimum value, while the $T_{\text {onset }}$ of the main degradation registered in the TGA analyses was taken as the maximum applicable temperatures. It is worth stressing that no substantial differences can be noted when the linker between the two benzimidazolium heads is varied, except for compound 7. Indeed, this specific system showed a wider operative range both considering the melting temperature registered in the first heating run (blue bar) and especially the glass transition observed in the second heating run (green bar) of DSC analysis.

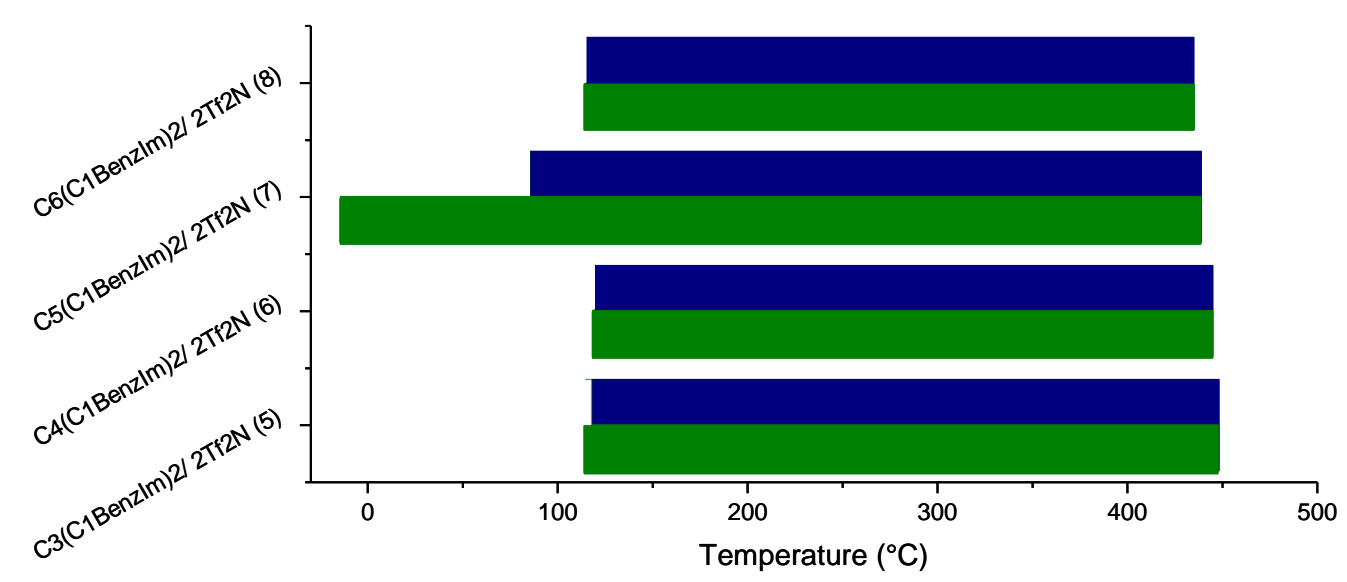

Figure 4. Operative range of $\mathrm{Tf}_{2} \mathrm{~N}$ BDILs: the blue bars and green bars were obtained by using a minimum value of the temperature of the transition of the first heating run and the second heating run of DSC analyses, respectively. As the maximum value of temperature, $T_{\text {onset }}$ of the main degradation obtained by TGA analyses was taken in both cases.

\subsection{Electrochemical Window Determination}

The electrochemical window (ECW) of BDILs 5-8 has been estimated through cyclic voltammetry of $0.1 \mathrm{M}$ solution in acetonitrile, using a platinum working electrode. The results are reported in Figure 5.

Although BDILs 5-8 showed very similar electrochemical stability properties, it was possible to appreciate a slight widening of the ECW with the elongation of the linker chain. Compound 5 displayed an ECW of about $4 \mathrm{~V}, 6$ and 7 of $4.1 \mathrm{~V}$ and 8 was found to exhibit 
the largest ECW with $4.2 \mathrm{~V}$. Having all the considered BDILs the same resistance toward oxidation, the only differences could be appreciated on the cathodic side of the ECW, related with the cation stability toward reduction [104-106]. A few studies have already been reported where the cathodic behavior of imidazolium ILs are presented: [104,105] they indicate the possibility of the formation of N-heterocyclic carbene (NHC) species at potential lower than $-2 \mathrm{~V}$ vs. $\mathrm{Ag} / \mathrm{AgCl}$. More specifically, the reduction in dicationic systems has been described as influenced by the length of the linker chain connecting the imidazolium groups, suggesting a cooperative effect between the aromatic rings [105]. Consistent with these data, the cyclic voltammetry experiments of the benzimidazolium DILs reported in this work also show a strong dependence on the linker chain. Interestingly, not only the reduction peak potential was affected, but also its shape and intensity (Figure 6). BDILs 7 and 8 showed a composite reduction peak and, symmetrically, an enlarged oxidation signal centered around the $0.25-0.50 \mathrm{~V}$ region. The elongation of the linker chain appears to hinder the simultaneous reduction in the two benzimidazolium groups observed for the shorter chain BDILs 5 and $\mathbf{6}$, resulting in the manifestation of a double reduction and of the related oxidation signals.

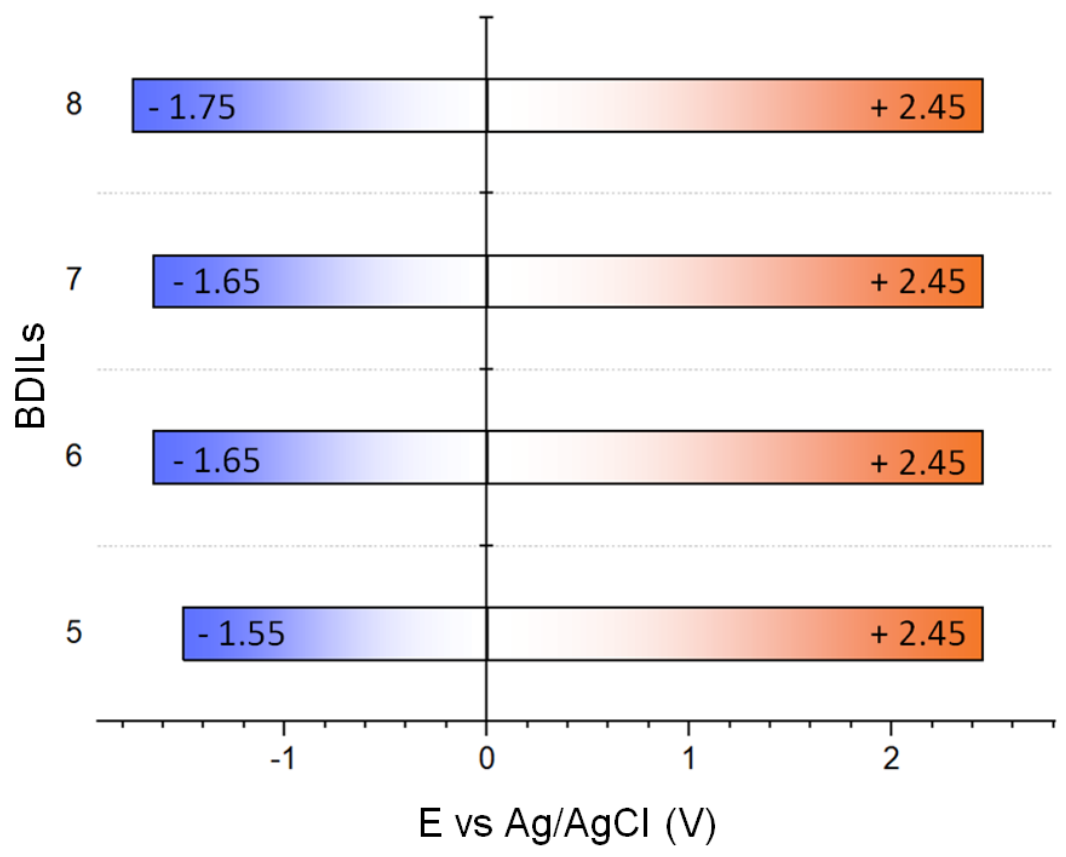

Figure 5. ECW comparison of BDILs 5-8.

a)

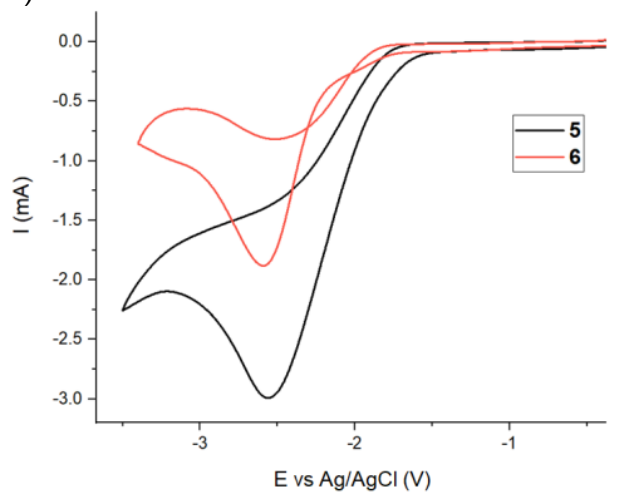

b)

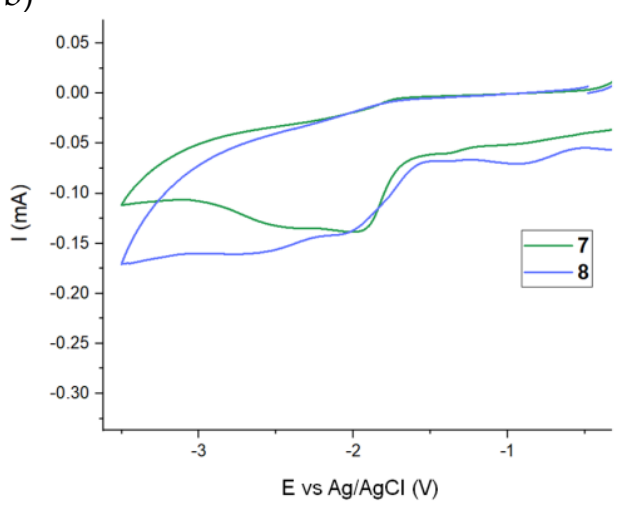

Figure 6. (a) Cyclic voltammetries of BDILs 5 and $60.01 \mathrm{M}$ in MeCN at $100 \mathrm{mV} \mathrm{s}^{-1}$; (b) cyclic voltammetries of BDILs 7 and $80.01 \mathrm{M}$ in $\mathrm{MeCN}$ at $100 \mathrm{mV} \mathrm{s}^{-1}$. 
Concerning the NHC reduction product, it is possible to consider, on the basis of literature data, the formation of tetraazafulvene-like cyclic structures through the intramolecular coupling of the carbenes. Toward this end, cyclic voltammograms between $-3.5 \mathrm{~V}$ and $+2 \mathrm{~V}$ (potential within which NHC or its related dimer should be oxidized) have been analyzed. It is reported by Broggi et al. [94] that the NHC dimer reduction potential is at about $-0.76 \mathrm{~V}$; however, no clear signals were found in the region. These results confirm the absence of bridged cation formation but cannot help drawing any conclusion on the formation of the neutral dimer under our experimental conditions.

\section{Materials and Methods}

\subsection{Material and Instruments}

1-Methylbenzimidazole ( $>98 \%$ ) was purchased from TCI Chemicals. 1,3-Dibromopropane (99\%), 1,4-dibromobutane (99\%), 1,5-dibromopentane (97\%), 1,6-Dibromohexane (96\%), acetonitrile $(99.5 \%)$, diethyl ether $(99.7 \%)$ and dichloromethane $(99.8 \%)$, were obtained from Merck Life Science S.r.l. (Darmstadt, Germania) Lithium bis(trifuoromethylsulfonyl)imide was purchased from Merck Life Science S.r.l. (Darmstadt, Germania) All reagents were used as received without further purification.

NMR spectra were recorded with a Bruker Avance II (Bruker Italia S.r.l., Milano, Italy) operating at $400\left({ }^{1} \mathrm{H}\right)$ and $100 \mathrm{MHz}\left({ }^{13} \mathrm{C}\right)$ and using deuterated methanol as solvent. Chemical shifts $(\delta)$ are referenced to the residual solvent signal of $\mathrm{CD}_{3} \mathrm{OD}\left({ }^{1} \mathrm{H} 3.31 \mathrm{ppm}\right.$, ${ }^{13} \mathrm{C} 49.0 \mathrm{ppm}$ ) while coupling constants $(J)$ are expressed in Hertz $(\mathrm{Hz})$. The following abbreviations are used: $\mathrm{s}=$ singlet, $\mathrm{m}=$ multiplet, $\mathrm{t}=$ triplet, $\mathrm{q}=$ quartet.

The thermal stability of the synthesized ILs was investigated by thermal gravimetric analysis (TGA), conducted in a TA Instruments Q500 TGA (New Castle, DE, USA) equipped with an EGA(Evolved Gas Analysis) furnace. The thermal behavior of the ionic liquids was analyzed by a differential scanning calorimeter TA Instruments DSC, Q250 (TA Instruments, New Castle, DE, USA).

Cyclic voltammetry $(\mathrm{CV})$ analysis was performed with a conventional three-electrode cell equipped with a reference electrode (Ag/ $\mathrm{AgCl} 3 \mathrm{M} \mathrm{KCl}$, Amel 373/SSG/6), a counter electrode (platinum wire, Amel 805/SPG/12), and a working electrode consisting of a glassy carbon disk (GC, $0.07 \mathrm{~cm}^{2}$ area). A VMP3 Biologic Science Instrument device was used as a potentiostat (EC-lab V10.18 software was used to control the potentiostat).

\subsection{Synthesis of DILs}

3.2.1. General Procedure for Synthesis of Bromide Benzimidazole Dicationic Ionic Liquids (Bdils)

The bromide benzimidazole dicationic ionic liquids (BDILs) were obtained following a general procedure previously reported [38]. To a solution of opportune 1,n-dibromoalcane $(1 \mathrm{~mol})$ in dry acetonitrile $(25 \mathrm{~mL})$, a solution of commercial $\mathrm{N}$-methylbenzimidazole $(2.6$ $\mathrm{mol}$ in $20 \mathrm{~mL}$ of dry acetonitrile) was added, and the reaction mixture was heated to $80^{\circ} \mathrm{C}$ and stirred under nitrogen atmosphere. After $24 \mathrm{~h}$, the solution was cooled to room temperature, diethyl ether $\left(\mathrm{Et}_{2} \mathrm{O}, 30 \mathrm{~mL}\right)$ was added, and immediately, the precipitation of a white solid was observed. Solid precipitates were filtrated under vacuum, washed with diethyl ether $(3 \times 50 \mathrm{~mL})$, and dried in vacuo to afford white solids in excellent yields.

\subsubsection{General Procedure of the Metathesis Reaction}

Bis[(trifluoromethyl)sulfonyl]imide $\left(\mathrm{Tf}_{2} \mathrm{~N}\right)$ benzimidazole dicationic ionic liquids were obtained following a general procedure previously reported [12,35]. A water solution of lithium bis(trifuoromethylsulfonyl)imide ( $80 \% w / w, 1.2$ equiv.) was added dropwise to an aqueous solution of opportune bromide benzimidazole dicationic ionic liquid (1 equiv., $10 \mathrm{~mL}$ ). The suspension was stirred for $12 \mathrm{~h}$ at room temperature, and then $15 \mathrm{~mL}$ of dichloromethane was added. The organic phase was separated and washed with deionized water $(3 \times 15 \mathrm{~mL})$ until bromide could not be detected $\left(\mathrm{AgNO}_{3}\right.$ test). The organic phase 
was dried over $\mathrm{Na}_{2} \mathrm{SO}_{4}$, filtered, and evaporated under reduced pressure to provide a white solid in quantitative yields.

3.2.3. 3,3'-(Propane-1,3-diyl)bis(1-methyl-1H-benzimidazolium) Dibromide $\mathrm{C}_{3}\left(\mathrm{C}_{1} \text { BenzIm }\right)_{2} / 2 \mathrm{Br}$

The synthesis of $C_{3}\left(C_{1} \text { BenzIm }\right)_{2} / 2 \mathrm{Br}(1,97 \%$ yield, white solid $)$ was performed according to the general procedure described above for the preparation of the bromide BDILs. ${ }^{1} \mathrm{H}$ NMR $\left(\mathrm{CD}_{3} \mathrm{OD}\right.$, after $\left.2 \mathrm{~h}\right) \delta 9.69(\mathrm{~s}, 2 \mathrm{H}, 2 \times \mathrm{H}-2), 8.13-8.08(\mathrm{~m}, 2 \mathrm{H}, \mathrm{Ar}-\mathrm{H}), 7.99-7.94(\mathrm{~m}$, $2 \mathrm{H}, \mathrm{Ar}-\mathrm{H}), 7.77-7.70(\mathrm{~m}, 4 \mathrm{H}, \mathrm{Ar}-\mathrm{H}), 4.82\left(\mathrm{t}, 4 \mathrm{H}, \mathrm{J}_{\mathrm{vic}}=7.4 \mathrm{~Hz}, 2 \times \mathrm{CH}_{2} \mathrm{~N}\right), 4.16(\mathrm{~s}, 6 \mathrm{H}, 2 \times$ $\left.\mathrm{CH}_{3} \mathrm{~N}\right), 2.84-2.79\left(\mathrm{~m}, 2 \mathrm{H}, \mathrm{CH}_{2}\right) ;{ }^{13} \mathrm{C}$ NMR $\left(\mathrm{CD}_{3} \mathrm{OD}\right.$, after $\left.24 \mathrm{~h}\right) \delta 143.4(\mathrm{t}, \mathrm{J}=33.5 \mathrm{~Hz}, 2 \times$ C-2), 133.7, $132.7(4 \times \mathrm{Ar}-\mathrm{C}), 128.3(4 \times \mathrm{Ar}-\mathrm{CH}), 114.5(4 \times \mathrm{Ar}-\mathrm{CH}), 45.4\left(2 \times \mathrm{CH}_{2} \mathrm{~N}\right), 34.0$ $\left(2 \times \mathrm{CH}_{3} \mathrm{~N}\right), 30.0\left(\mathrm{CH}_{2}\right)$. NMR data $\left({ }^{1} \mathrm{H}\right.$ and $\left.{ }^{13} \mathrm{C}\right)$ were in agreement with those reported in DMSO-d $_{6}[87,107]$.

3.2.4. 3,3'-(Butane-1,4-diyl)bis(1-methyl-1H-benzimidazolium) Dibromide $\mathrm{C}_{4}\left(\mathrm{C}_{1} \text { BenzIm }\right)_{2} / 2 \mathrm{Br}(2)$

The synthesis of $C_{4}\left(C_{1} \text { BenzIm }\right)_{2} / 2 \mathrm{Br}(2,98 \%$ yield, white solid $)$ was performed according to the general procedure described above for the preparation of the bromide BDILs. ${ }^{1} \mathrm{H}$ NMR $\left(\mathrm{CD}_{3} \mathrm{OD}\right.$, after $\left.20 \mathrm{~min}\right) \delta 9.62(\mathrm{~s}, 2 \mathrm{H}, 2 \times \mathrm{H}-2), 8.07-8.01(\mathrm{~m}, 2 \mathrm{H}, \mathrm{Ar}-\mathrm{H}), 7.98-7.91$ $(\mathrm{m}, 2 \mathrm{H}, \mathrm{Ar}-\mathrm{H}), 7.75-7.68(\mathrm{~m}, 4 \mathrm{H}, \mathrm{Ar}-\mathrm{H}), 4.67-4.60\left(\mathrm{~m}, 4 \mathrm{H}, 2 \times \mathrm{CH}_{2} \mathrm{~N}\right), 4.16(\mathrm{~s}, 6 \mathrm{H}, 2 \times$ $\left.\mathrm{CH}_{3} \mathrm{~N}\right), 2.24-2.15\left(\mathrm{~m}, 4 \mathrm{H}, 2 \times \mathrm{CH}_{2} \mathrm{CH}_{2} \mathrm{~N}\right) ;{ }^{13} \mathrm{C} \mathrm{NMR}\left(\mathrm{CD}_{3} \mathrm{OD}\right.$, after $\left.2 \mathrm{~h}\right) \delta 143.5(2 \times \mathrm{C}-2)$, 133.7, $132.7(4 \times \mathrm{Ar}-\mathrm{C}), 128.2,128.2(4 \times \mathrm{Ar}-\mathrm{CH}), 114.5,114.4(4 \times \mathrm{Ar}-\mathrm{CH}), 47.7\left(2 \times \mathrm{CH}_{2} \mathrm{~N}\right)$, $34.0\left(2 \times \mathrm{CH}_{3} \mathrm{~N}\right), 27.3\left(2 \times \mathrm{CH}_{2} \mathrm{CH}_{2} \mathrm{~N}\right)$. NMR data $\left({ }^{1} \mathrm{H}\right.$ and $\left.{ }^{13} \mathrm{C}\right)$ were in agreement with those reported in DMSO- $d_{6}$ [87].

3.2.5. 3,3'-(Pentane-1,5-diyl)bis(1-methyl-1H-benzimidazolium) Dibromide $\mathrm{C}_{5}\left(\mathrm{C}_{1} \text { BenzIm }\right)_{2} / 2 \mathrm{Br}(3)$

The synthesis of $C_{5}\left(C_{1} \text { BenzIm }\right)_{2} / 2 B r(3,98 \%$ yield, white solid) was performed according to the general procedure described above for the preparation of the bromide BDILs. ${ }^{1} \mathrm{H}$ NMR $\left(\mathrm{CD}_{3} \mathrm{OD}\right.$, after $\left.10 \mathrm{~min}\right) \delta 9.63(\mathrm{~s}, 2 \mathrm{H}, 2 \times \mathrm{H}-2), 8.04-7.99(\mathrm{~m}, 2 \mathrm{H}, \mathrm{Ar}-\mathrm{H}), 7.98-7.94$ $(\mathrm{m}, 2 \mathrm{H}, \mathrm{Ar}-\mathrm{H}), 7.75-7.68(\mathrm{~m}, 4 \mathrm{H}, \mathrm{Ar}-\mathrm{H}), 4.59\left(\mathrm{t}, 4 \mathrm{H}, J_{\mathrm{vic}}=7.3 \mathrm{~Hz}, 2 \times \mathrm{CH}_{2} \mathrm{~N}\right), 4.17(\mathrm{~s}, 6 \mathrm{H}, 2$ $\left.\times \mathrm{CH}_{3} \mathrm{~N}\right), 2.17-2.10\left(\mathrm{~m}, 4 \mathrm{H}, 2 \times \mathrm{CH}_{2} \mathrm{CH}_{2} \mathrm{~N}\right), 1.64-1.56\left(\mathrm{~m}, 2 \mathrm{H}, \mathrm{CH}_{2}\right) ;{ }^{13} \mathrm{C} \mathrm{NMR}\left(\mathrm{CD}_{3} \mathrm{OD}\right.$, after $24 \mathrm{~h}) \delta 143.2(\mathrm{t}, J=31.4 \mathrm{~Hz}, 2 \times \mathrm{C}-2), 133.7,132.8(4 \times \mathrm{Ar}-\mathrm{C}), 128.2(4 \times \mathrm{Ar}-\mathrm{CH}), 114.45$, $114.4(4 \times \mathrm{Ar}-\mathrm{CH}), 48.3\left(2 \times \mathrm{CH}_{2} \mathrm{~N}\right), 33.9\left(2 \times \mathrm{CH}_{3} \mathrm{~N}\right), 30.0\left(2 \times \mathrm{CH}_{2} \mathrm{CH}_{2} \mathrm{~N}\right), 26.9\left(\mathrm{CH}_{2}\right)$.

3.2.6. 3,3'-(Hexane-1,6-Diyl)Bis(1-Methyl-1H-Benzimidazolium) dibromide $\mathrm{C}_{6}\left(\mathrm{C}_{1} \text { BenzIm }\right)_{2} / 2 \mathrm{Br}(4)$

The synthesis of $\mathrm{C}_{6}\left(\mathrm{C}_{1} \text { BenzIm }\right)_{2} / 2 \mathrm{Br}(4,97 \%$ yield, white solid $)$ was performed according to the general procedure described above for the preparation of the bromide BDILs. ${ }^{1} \mathrm{H}$ NMR $\left(\mathrm{CD}_{3} \mathrm{OD}\right.$, after $\left.10 \mathrm{~min}\right) \delta 9.60(\mathrm{~s}, 2 \mathrm{H}, 2 \times \mathrm{H}-2), 8.02-7.99(\mathrm{~m}, 2 \mathrm{H}, \mathrm{Ar}-\mathrm{H}), 7.97-7.94$ $(\mathrm{m}, 2 \mathrm{H}, \mathrm{Ar}-\mathrm{H}), 7.74-7.71(\mathrm{~m}, 4 \mathrm{H}, \mathrm{Ar}-\mathrm{H}), 4.56\left(\mathrm{t}, 4 \mathrm{H}, J_{\mathrm{vic}}=7.3 \mathrm{~Hz}, 2 \times \mathrm{CH}_{2} \mathrm{~N}\right), 4.16(\mathrm{~s}, 6 \mathrm{H}, 2 \times$ $\left.\mathrm{CH}_{3} \mathrm{~N}\right), 2.08-2.04\left(\mathrm{~m}, 4 \mathrm{H}, 2 \times \mathrm{CH}_{2} \mathrm{CH}_{2} \mathrm{~N}\right), 1.57-1.53\left(\mathrm{~m}, 4 \mathrm{H}, \mathrm{CH}_{2} \mathrm{CH}_{2}\right) ;{ }^{13} \mathrm{C} \mathrm{NMR}\left(\mathrm{CD}_{3} \mathrm{OD}\right.$, after $24 \mathrm{~h}) \delta 143.1(\mathrm{t}, J=33.10 \mathrm{~Hz}, 2 \times \mathrm{C}-2), 133.7,132.8(4 \times \mathrm{Ar}-\mathrm{C}), 128.2(4 \times \mathrm{Ar}-\mathrm{CH})$, 114.4, $114.3(4 \times \mathrm{Ar}-\mathrm{CH}), 48.2\left(2 \times \mathrm{CH}_{2} \mathrm{~N}\right), 33.9\left(2 \times \mathrm{CH}_{3} \mathrm{~N}\right), 30.0\left(2 \times \mathrm{CH}_{2} \mathrm{CH}_{2} \mathrm{~N}\right), 26.9$ $\left(\mathrm{CH}_{2} \mathrm{CH}_{2}\right)$.

3.2.7. 3,3'-(Propane-1,3-Diyl)Bis(1-Methyl-1H-Benzimidazolium) diBis[(Trifluoromethyl)Sulfonyl]Imide $C_{3}\left(C_{1} \text { BenzIm }\right)_{2} / 2 \mathrm{Tf}_{2} \mathrm{~N}(5)$

The synthesis of $C_{3}\left(C_{1} \text { BenzIm }\right)_{2} / 2 \mathrm{Br}$ (5, 99\% yield, white solid) was performed according to the general procedure described above for the preparation of the bis[(trifluoromethyl)sulfonyl] imide BDILs. ${ }^{1} \mathrm{H}$ NMR $\left(\mathrm{CD}_{3} \mathrm{OD}\right.$, after $\left.2 \mathrm{~h}\right) \delta 9.39(\mathrm{~s}, 2 \mathrm{H}, 2 \times \mathrm{H}-2), 8.01-7.98(\mathrm{~m}, 2 \mathrm{H}, \mathrm{Ar}-\mathrm{H})$, 7.97-7.93 (m, 2H, Ar- $H), 7.77-7.71(\mathrm{~m}, 4 \mathrm{H}, \mathrm{Ar}-\mathrm{H}), 4.73\left(\mathrm{t}, 4 \mathrm{H}, J_{\mathrm{vic}}=7.5 \mathrm{~Hz}, 2 \times \mathrm{CH}_{2} \mathrm{~N}\right), 4.13(\mathrm{~s}$, $\left.6 \mathrm{H}, 2 \times \mathrm{CH}_{3} \mathrm{~N}\right), 2.80-2.75\left(\mathrm{~m}, 2 \mathrm{H}, \mathrm{CH}_{2}\right) ;{ }^{13} \mathrm{C} \mathrm{NMR}\left(\mathrm{CD}_{3} \mathrm{OD}\right.$, after $\left.24 \mathrm{~h}\right) \delta 143.1(\mathrm{t}, J=32.0 \mathrm{~Hz}$, $2 \times \mathrm{C}-2), 133.7,132.6(4 \times \mathrm{Ar}-\mathrm{C}), 128.5(4 \times \mathrm{Ar}-\mathrm{CH}), 121.2\left(\mathrm{q}, J_{\mathrm{C}, \mathrm{F}}=320.7 \mathrm{~Hz}, 4 \times \mathrm{CF}_{3}\right), 114.5$, $114.2(4 \times \mathrm{Ar}-\mathrm{CH}), 45.3\left(2 \times \mathrm{CH}_{2} \mathrm{~N}\right), 33.9\left(2 \times \mathrm{CH}_{3} \mathrm{~N}\right), 29.9\left(\mathrm{CH}_{2}\right)$. 
3.2.8. 3,3'-(Butane-1,4-Diyl)Bis(1-Methyl-1H-Benzimidazolium)

diBis[(Trifluoromethyl)Sulfonyl]Imide $\mathrm{C}_{4}\left(\mathrm{C}_{1} \text { BenzIm }\right)_{2} / 2 \mathrm{Tf}_{2} \mathrm{~N}$ (6)

The synthesis of $\mathrm{C}_{4}\left(\mathrm{C}_{1} \text { BenzIm }\right)_{2} / 2 \mathrm{Tf}_{2} \mathrm{~N}(6,99 \%$ yield, white solid) was performed according to the general procedure described above for the preparation of the bis[(trifluoromethyl) sulfonyl]imide BDILs. ${ }^{1} \mathrm{H}$ NMR $\left(\mathrm{CD}_{3} \mathrm{OD}\right.$, after $\left.2 \mathrm{~h}\right) \delta 9.62(\mathrm{~s}, 2 \mathrm{H}, 2 \times \mathrm{H}-2), 7.99-7.92(\mathrm{~m}, 4 \mathrm{H}$, $\mathrm{Ar}-\mathrm{H}), 7.75-7.68(\mathrm{~m}, 4 \mathrm{H}, \mathrm{Ar}-\mathrm{H}), 4.61-4.58\left(\mathrm{~m}, 4 \mathrm{H}, 2 \times \mathrm{CH}_{2} \mathrm{~N}\right), 4.12\left(\mathrm{~s}, 6 \mathrm{H}, 2 \times \mathrm{CH}_{3} \mathrm{~N}\right), 2.17-2.14$ $\left(\mathrm{m}, 4 \mathrm{H}, 2 \times \mathrm{CH}_{2} \mathrm{CH}_{2} \mathrm{~N}\right) ;{ }^{13} \mathrm{C} \mathrm{NMR}\left(\mathrm{CD}_{3} \mathrm{OD}\right.$, after $\left.24 \mathrm{~h}\right) \delta 143.0(\mathrm{t}, J=32.5 \mathrm{~Hz}, 2 \times \mathrm{C}-2), 133.7$, $132.7(4 \times \mathrm{Ar}-\mathrm{C}), 128.3(4 \times \mathrm{Ar}-\mathrm{CH}), 121.1\left(\mathrm{q}, J_{\mathrm{C}, \mathrm{F}}=320.7 \mathrm{~Hz}, 4 \times \mathrm{CF}_{3}\right), 114.4,114.3(4 \times \mathrm{Ar}-\mathrm{CH})$, $47.7\left(2 \times \mathrm{CH}_{2} \mathrm{~N}\right), 33.8\left(2 \times \mathrm{CH}_{3} \mathrm{~N}\right), 27.2\left(2 \times \mathrm{CH}_{2} \mathrm{CH}_{2} \mathrm{~N}\right)$.

3.2.9. 3,3'-(Pentane-1,5-Diyl)bis(1-Methyl-1H-Benzimidazolium) diBis[(Trifluoromethyl)Sulfonyl]Imide $\mathrm{C}_{5}\left(\mathrm{C}_{1} \text { BenzIm }\right)_{2} / 2 \mathrm{Tf}_{2} \mathrm{~N}(7)$

The synthesis of $\mathrm{C}_{5}\left(\mathrm{C}_{1} \text { BenzIm }\right)_{2} / 2 \mathrm{Tf}_{2} \mathrm{~N}(7,99 \%$ yield, white solid) was performed according to the general procedure described above for the preparation of the bis[(trifluoromethyl) sulfonyl]imide BDILs. ${ }^{1} \mathrm{H}$ NMR $\left(\mathrm{CD}_{3} \mathrm{OD}\right.$, after $\left.2 \mathrm{~h}\right) \delta 9.29(\mathrm{~s}, 2 \mathrm{H}, 2 \times \mathrm{H}-2), 7.93-7.87(\mathrm{~m}, 4 \mathrm{H}$, Ar-H), 7.04-7.64 (m, 4H, Ar- H), $4.51\left(\mathrm{t}, 4 \mathrm{H}, J_{\text {vic }}=7.4 \mathrm{~Hz}, 2 \times \mathrm{CH}_{2} \mathrm{~N}\right), 4.10\left(\mathrm{~s}, 6 \mathrm{H}, 2 \times \mathrm{CH}_{3} \mathrm{~N}\right)$, 2.14-2.06 (m, 4H, $\left.2 \times \mathrm{CH}_{2} \mathrm{CH}_{2} \mathrm{~N}\right), 1.61-1.53\left(\mathrm{~m}, 2 \mathrm{H}, \mathrm{CH}_{2}\right) ;{ }^{13} \mathrm{C} \mathrm{NMR}\left(\mathrm{CD}_{3} \mathrm{OD}\right.$, after $\left.24 \mathrm{~h}\right) \delta 142.7$ $(\mathrm{t}, J=33.3 \mathrm{~Hz}, 2 \times \mathrm{C}-2), 133.5,132.7(4 \times \mathrm{Ar}-\mathrm{C}), 128.1(4 \times \mathrm{Ar}-\mathrm{CH}), 121.1\left(\mathrm{q}, J_{\mathrm{C}, \mathrm{F}}=320.6 \mathrm{~Hz}, 4 \times\right.$ $\left.\mathrm{CF}_{3}\right), 114.2(4 \times \mathrm{Ar}-\mathrm{CH}), 48.0\left(2 \times \mathrm{CH}_{2} \mathrm{~N}\right), 33.8\left(2 \times \mathrm{CH}_{3} \mathrm{~N}\right), 29.7\left(2 \times \mathrm{CH}_{2} \mathrm{CH}_{2} \mathrm{~N}\right), 24.4\left(\mathrm{CH}_{2}\right)$.

3.2.10. 3,3'-(Hexane-1,5-Diyl)Bis(1-Methyl-1H-Benzimidazolium) diBis[(Trifluoromethyl)Sulfonyl]Imide $\mathrm{C}_{6}\left(\mathrm{C}_{1} \text { BenzIm) }\right)_{2} / 2 \mathrm{Tf}_{2} \mathrm{~N}(\mathbf{8})$

The synthesis of $\mathrm{C}_{6}\left(\mathrm{C}_{1} \text { BenzIm }\right)_{2} / 2 \mathrm{Tf}_{2} \mathrm{~N}(8,99 \%$ yield, white solid) was performed according to the general procedure described above for the preparation of the bis[(trifluoromethyl) sulfonyl]imide BDILs. ${ }^{1} \mathrm{H}$ NMR $\left(\mathrm{CD}_{3} \mathrm{OD}\right.$, after $\left.2 \mathrm{~h}\right) \delta 9.34(\mathrm{~s}, 2 \mathrm{H}, 2 \times \mathrm{H}-2), 7.96-7.90(\mathrm{~m}, 4 \mathrm{H}$, Ar-H), 7.73-7.67 (m, 4H, Ar- $H), 4.51\left(\mathrm{t}, 4 \mathrm{H}, J_{\text {vic }}=7.3 \mathrm{~Hz}, 2 \times \mathrm{CH}_{2} \mathrm{~N}\right), 4.12\left(\mathrm{~s}, 6 \mathrm{H}, 2 \times \mathrm{CH}_{3} \mathrm{~N}\right)$, 2.08-2.00 (m, 4H, $\left.2 \times \mathrm{CH}_{2} \mathrm{CH}_{2} \mathrm{~N}\right), 1.55-1.51\left(\mathrm{~m}, 4 \mathrm{H}, \mathrm{CH}_{2} \mathrm{CH}_{2}\right) ;{ }^{13} \mathrm{C} \mathrm{NMR}\left(\mathrm{CD}_{3} \mathrm{OD}\right.$, after $\left.24 \mathrm{~h}\right) \delta$ $143.8(\mathrm{t}, J=32.6 \mathrm{~Hz}, 2 \times \mathrm{C}-2), 133.6,132.8(4 \times \mathrm{Ar}-\mathrm{C}), 128.2(4 \times \mathrm{Ar}-\mathrm{CH}), 121.2\left(\mathrm{q}, J_{\mathrm{C}, \mathrm{F}}=322.6 \mathrm{~Hz}\right.$, $\left.4 \times \mathrm{CF}_{3}\right), 114.3,114.3(4 \times \mathrm{Ar}-\mathrm{CH}), 48.3\left(2 \times \mathrm{CH}_{2} \mathrm{~N}\right), 33.7\left(2 \times \mathrm{CH}_{3} \mathrm{~N}\right), 30.0\left(2 \times \mathrm{CH}_{2} \mathrm{CH}_{2} \mathrm{~N}\right)$, $26.9\left(\mathrm{CH}_{2} \mathrm{CH}_{2}\right)$.

\subsection{Thermal Analysis}

Prior to TGA and DSC measurement, all samples were dried in high vacuum at $60{ }^{\circ} \mathrm{C}$ for $24 \mathrm{~h}$ to remove moisture.

\subsubsection{Thermal Gravimetric Analysis}

The thermal stability of the synthesized ILs was investigated by using thermal gravimetric analysis (TA Instruments Q500 TGA, New Castle, DE, USA). The instrument was calibrated using weight standards $(1 \mathrm{~g}$ and $100 \mathrm{mg})$. The temperature calibration was performed using nickel standards. All the standards were supplied by TA Instruments Inc (New Castle, DE, USA). The sample (10-15 mg) was heated at $60{ }^{\circ} \mathrm{C}$ in a platinum crucible for the drying procedure and maintained in $\mathrm{N}_{2}$ flux $(90 \mathrm{~mL} / \mathrm{min})$ for $30 \mathrm{~min}$. Then, BDIL was heated from 40 to $700{ }^{\circ} \mathrm{C}$ with a heating rate of $10{ }^{\circ} \mathrm{C} / \mathrm{min}$ under nitrogen $(90 \mathrm{~mL} / \mathrm{min})$ and maintained at $700{ }^{\circ} \mathrm{C}$ for $3 \mathrm{~min}$. The mass change was recorded as a function of temperature and time. TGA experiments were carried out in duplicate.

\subsubsection{Differential Scanning Calorimetry}

The thermal behavior of the ionic liquids was analyzed by using a differential scanning calorimeter (TA DSC Q250, New Castle, DE, USA). The temperature calibration was performed considering the heating rate dependence of the onset temperature of the melting peak of indium. In order to allow volatile compounds to escape and to avoid the risk of the pan bursting under pressure, a small incision was made at the top of both the sample and the reference pan. The sample (3-5 mg) was loaded in Tzero hermetic aluminum pan (TA Instruments), and the phase behavior was explored under nitrogen atmosphere $(30 \mathrm{~mL} / \mathrm{min})$ in the temperature range of -90 to $200{ }^{\circ} \mathrm{C}$ at different scanning rates of 
(2-10 ${ }^{\circ} \mathrm{C} / \mathrm{min}$ ). DSC experiments were carried out in duplicate. $T_{\mathrm{g}}$ was obtained by taking the onset of the heat capacity change on heating from a glass to a liquid. $T_{\mathrm{cc}}$ was determined as the peak temperature of the exothermic peak on heating from a subcooled liquid to a crystalline solid. $T_{\mathrm{m}}$ was taken as the peak temperature of the endothermic peak on the heating run. The peak temperatures were chosen instead of the onset temperatures due to the complexity of the thermograms.

\subsubsection{Cyclic Voltammetry}

Cyclic voltammetry (CV) experiments were conducted at room temperature under $\mathrm{N}_{2}$ on previously deaerated samples, in a potential range between -2.00 and $3.20 \mathrm{~V}$ (vs. $\mathrm{Ag} / \mathrm{AgCl}$ ) at $100 \mathrm{mVs}^{-1}$ potential scan rate. Electrochemical stability windows (ECW) have been reported considering the cathodic and anodic limits as the $\mathrm{CV}$ onset potentials.

\section{Conclusions}

A series of dicationic ionic liquids, based on the same methyl benzimidazole cationic core but bearing alkyl spacers of different lengths, were prepared and profiled. The ILs in question, belonging to two structurally related families of dicationic ionic liquids, feature C 3 to $\mathrm{C} 6$ spacers between the benzimidazole cores and are characterized by either bromide or bistriflimide counter anions. The systematic study of their thermal properties and the cyclic voltammetry analysis elucidated the effect of the different anions and of the spacer length on their properties and behavior. While the thermogravimetric analysis only confirmed the expected higher stability of the bistriflimide ILs when compared to the bromide ILs, on account of the higher nucleophilicity of the halide anion, DSC analysis presented a more complex picture. Indeed, in the case of the bistriflimide series, all possible types of thermal behavior for ILs were found. Therefore, within this family, the distance between the cationic headgroups plays a dramatic effect on whether or not a phase transition may occur. This reflects in a different liquid range, which is the widest in the case of $\mathrm{C}_{5}\left(\mathrm{C}_{1} \text { BenzIm }\right)_{2} / 2 \mathrm{Tf}_{2} \mathrm{~N}$. Again, cyclic voltammetry showed different electrochemical windows $\left(\mathrm{C}_{3}\left(\mathrm{C}_{1} \text { BenzIm }\right)_{2} / 2 \mathrm{Tf}_{2} \mathrm{~N}<\mathrm{C}_{4}\left(\mathrm{C}_{1} \text { BenzIm }\right)_{2} / 2 \mathrm{Tf}_{2} \mathrm{~N}, \mathrm{C}_{5}\left(\mathrm{C}_{1} \text { BenzIm }\right)_{2} / 2 \mathrm{Tf}_{2} \mathrm{~N}<\right.$ $\left.\mathrm{C}_{6}\left(\mathrm{C}_{1} \text { BenzIm }\right)_{2} / 2 \mathrm{Tf}_{2} \mathrm{~N}\right)$ as well as a reduction in peak potential, shape, and intensity as a function of the spacer length.

On the basis of the presented results, it would be of interest to investigate the effect of the linker length on the catalytic activities of the proposed BDILs in organic reactions and on the ability to furnish organic super-electron donors.

Supplementary Materials: The following are available online, Figure S1. ${ }^{1} \mathrm{H}$ NMR of compound 1 , Figure S2. ${ }^{13} \mathrm{C}$ NMR of compound 1, Figure S3. ${ }^{1} \mathrm{H}$ NMR of compound 2, Figure S4. ${ }^{13} \mathrm{C}$ NMR of compound 2, Figure S5. ${ }^{1} \mathrm{H}$ NMR of compound 3 (after $10 \mathrm{~min}$ ), Figure S6. ${ }^{1} \mathrm{H}$ NMR of compound 3 (after $24 \mathrm{~h}$ ), Figure S7. ${ }^{1} \mathrm{H}$ NMR of compound 3 (after $10 \mathrm{~min}$ and $24 \mathrm{~h}$ ), Figure S8. ${ }^{13} \mathrm{C}$ NMR of compound 3, Figure S9. ${ }^{1} \mathrm{H}$ NMR of compound 4 (after $15 \mathrm{~min}$ ), Figure S10. ${ }^{1} \mathrm{H}$ NMR of compound 4 (after $24 \mathrm{~h}$ ), Figure S11. ${ }^{1} \mathrm{H}$ NMR of compound 4 (after $15 \mathrm{~min}$ and $24 \mathrm{~h}$ ), Figure S12. ${ }^{13} \mathrm{C}$ NMR of compound 4 (after $2 \mathrm{~h}$ ), Figure S13. ${ }^{13} \mathrm{C}$ NMR of compound 4 (after $24 \mathrm{~h}$ ), Figure S14. ${ }^{13} \mathrm{C}$ NMR of compound 4 (after $2 \mathrm{~h}$ and $24 \mathrm{~h}$ ), Figure S15. ${ }^{1} \mathrm{H}$ NMR of compound 5, Figure S16. ${ }^{13} \mathrm{C}$ NMR of compound 5, Figure S17. ${ }^{1} \mathrm{H}$ NMR of compound 6, Figure S18. ${ }^{13} \mathrm{C}$ NMR of compound 6, Figure S19. ${ }^{1} \mathrm{H}$ NMR of compound 7, Figure S20. ${ }^{13} \mathrm{C}$ NMR of compound 7, Figure S21. ${ }^{1} \mathrm{H}$ NMR of compound 8, Figure S22. ${ }^{13} \mathrm{C}$ NMR of compound 8, Figure S23. TGA of compound 1, Figure S24. TGA of compound 2, Figure S25. TGA of compound 3, Figure S26. TGA of compound 4, Figure S27. TGA of compound 5, Figure S28: TGA of compound 6, Figure S29 TGA of compound 7, Figure S30. TGA of compound 8, Figure S31. DSC of compound 1, Figure S32. DSC of compound 2, Figure S33. DSC of compound 3, Figure S34. DSC of compound 4, Figure S35. DSC of compound 5, Figure S36. DSC of compound 6, Figure S37. DSC of compound 7, Figure S38. DSC of compound 8, Figure S39. Cyclic voltammetry of compound 5, Figure S40. Cyclic voltammetry of compound 6, Figure S41. Cyclic voltammetry of compound 7, Figure S42. Cyclic voltammetry of compound 8, Table S1. $\mathrm{T}_{\text {start }}, \mathrm{T}_{\text {onset, }}$ and $\mathrm{T}_{\text {peak }}$ of the investigated ionic liquids measured at heating rate of $10^{\circ} \mathrm{C} / \mathrm{min}$, Table S2. Melting temperature $\left(\mathrm{T}_{\mathrm{m}}\right)$, and enthalpy $\left(\mathrm{H}_{\mathrm{m}}\right)$ of the investigated ionic liquids measured at first heating run, 
Table S3. Glass transition temperature $\left(\mathrm{T}_{\mathrm{g}}\right)$, crystallization temperature $\left(\mathrm{T}_{\mathrm{c}}\right)$, cold crystallization temperature $\left(\mathrm{T}_{\mathrm{cc}}\right)$, and melting temperature $\left(\mathrm{T}_{\mathrm{m}}\right)$ of the investigated ionic liquids measured at second heating run, Table $\mathrm{S} 4$. Apparent activation energy $\left(\mathrm{E}_{\mathrm{a}}\right)$, consequently its fragility index $(\mathrm{m})$, and glass transition temperature $\left(\mathrm{T}_{\mathrm{g}} / \mathrm{K}\right)$ of compounds 7 .

Author Contributions: A.M. (Andrea Mezzetta) conceptualized and designed of the study, A.M (Andrea Mezzetta) and L.G. (Lorenzo Guazzelli) drafted and revised the article, A.M. (Angelica Mero) and G.T. prepared the BDILs, A.M. (Angelica Mero) and C.S.P. performed and analyzed the thermal analysis experiments, F.D. processed the NMR analysis, L.G. (Luca Guglielmero) performed and analyzed the CV measurements. All authors have read and agreed to the published version of the manuscript.

Funding: The research project was supported by Progetti di Ricerca di Ateneo PRA 2020 (cod PRA_2020_44).

Institutional Review Board Statement: Not applicable.

Informed Consent Statement: Not applicable.

Data Availability Statement: Not applicable.

Conflicts of Interest: "The authors declare no conflict of interest."

Sample Availability: Samples of the compounds are available from the authors.

\section{References}

1. Singh, S.; Savoy, A.W. Ionic liquids synthesis and applications: An overview. J. Mol. Liq. 2020, 297, 112038. [CrossRef]

2. Welton, T. Ionic liquids: A brief history. Biophys. Rev. 2018, 10, 691-706. [CrossRef] [PubMed]

3. Alexander, H. Tullo the time is now for ionic liquids. Chem. Eng. News 2020, 98, 3.

4. Egorova, K.S.; Gordeev, E.; Ananikov, V.P. Biological Activity of Ionic Liquids and Their Application in Pharmaceutics and Medicine. Chem. Rev. 2017, 117, 7132-7189. [CrossRef]

5. Renier, O.; Bousrez, G.; Yang, M.; Hoelter, M.; Mallick, B.; Smetana, V.; Mudring, A.-V. Developing design tools for introducing and tuning structural order in ionic liquids. CrystEngComm 2021, 23, 1785-1795. [CrossRef]

6. He, F.; Chen, J.; Gong, Z.; Xu, Q.; Yue, W.; Xie, H. Dissolution pretreatment of cellulose by using levulinic acid-based protic ionic liquids towards enhanced enzymatic hydrolysis. Carbohydr. Polym. 2021, 269, 118271. [CrossRef]

7. Mezzetta, A.; Becherini, S.; Pretti, C.; Monni, G.; Casu, V.; Chiappe, C.; Guazzelli, L. Insights into the levulinate-based ionic liquid class: Synthesis, cellulose dissolution evaluation and ecotoxicity assessment. New J. Chem. 2019, 43, 13010-13019. [CrossRef]

8. Xu, C.; Cheng, Z. Thermal Stability of Ionic Liquids: Current Status and Prospects for Future Development. Processes $2021,9,337$. [CrossRef]

9. Clarke, C.J.; Bui-Le, L.; Hallett, J.P.; Licence, P. Thermally-Stable Imidazolium Dicationic Ionic Liquids with Pyridine Functional Groups. ACS Sustain. Chem. Eng. 2020, 8, 8762-8772. [CrossRef]

10. Avila, J.; Lepre, L.F.; Santini, C.C.; Tiano, M.; Denis-Quanquin, S.; Szeto, K.C.; Padua, A.A.H.; Gomes, M.C. High-Performance

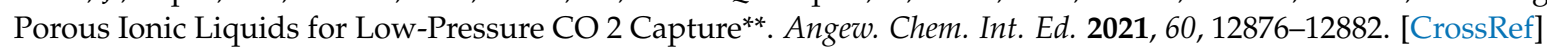

11. Arosa, Y.; Fernández, C.D.R.; Lago, E.L.; Amigo, A.; Varela, L.M.; Cabeza, O.; de la Fuente, R. Refractive index measurement of imidazolium based ionic liquids in the Vis-NIR. Opt. Mater. 2017, 73, 647-657. [CrossRef]

12. Barulli, L.; Mezzetta, A.; Brunetti, B.; Guazzelli, L.; Ciprioti, S.V.; Ciccioli, A. Evaporation thermodynamics of the tetraoctylphosphonium bis (trifluoromethansulfonyl) imide $\left(\left[\mathrm{P}_{8888}\right] \mathrm{NTf}_{2}\right)$ and tetraoctylphosphonium nonafluorobutane-1-sulfonate ([P8888] NFBS) ionic liquids. J. Mol. Liq. 2021, 333, 115892. [CrossRef]

13. Cimini, A.; Palumbo, O.; Simonetti, E.; De Francesco, M.; Appetecchi, G.B.; Fantini, S.; Lin, R.; Falgayrat, A.; Paolone, A. Decomposition temperatures and vapour pressures of selected ionic liquids for electrochemical applications. J. Therm. Anal. Calorim. 2020, 142, 1791-1797. [CrossRef]

14. Wu, H.-B.; Zhang, B.; Liu, S.-H.; Chen, C.-C. Flammability estimation of 1-hexyl-3-methylimidazolium bis (trifluoromethylsulfonyl) imide. J. Loss Prev. Process. Ind. 2020, 66, 104196. [CrossRef]

15. Hulsbosch, J.; De Vos, D.E.; Binnemans, K.; Ameloot, R. Biobased Ionic Liquids: Solvents for a Green Processing Industry? ACS Sustain. Chem. Eng. 2016, 4, 2917-2931. [CrossRef]

16. Flieger, J.; Flieger, M. Ionic Liquids Toxicity-Benefits and Threats. Int. J. Mol. Sci. 2020, 21, 6267. [CrossRef] [PubMed]

17. Florio, W.; Becherini, S.; D'Andrea, F.; Lupetti, A.; Chiappe, C.; Guazzelli, L. Comparative evaluation of antimicrobial activity of different types of ionic liquids. Mater. Sci. Eng. C 2019, 104, 109907. [CrossRef] [PubMed]

18. Hijo, A.T.; Maximo, G.J.; Costa, M.C.; Batista, E.A.C.; Meirelles, A.J.A. Applications of Ionic Liquids in the Food and Bioproducts Industries. ACS Sustain. Chem. Eng. 2016, 4, 5347-5369. [CrossRef]

19. Martins, P.; Braga, A.R.; De Rosso, V.V. Can ionic liquid solvents be applied in the food industry? Trends Food Sci. Technol. 2017, $66,117-124$. [CrossRef] 
20. Lu, B.; Yi, M.; Hu, S.; Wu, D.; Zhu, Z.; Wu, C.; Wang, Z.; Li, Y.; Zhang, J. Taurine-Based Ionic Liquids for Transdermal Protein Delivery and Enhanced Anticancer Activity. ACS Sustain. Chem. Eng. 2021, 9, 5991-6000. [CrossRef]

21. Demurtas, M.; Onnis, V.; Zucca, P.; Rescigno, A.; Lachowicz, J.I.; Engelbrecht, L.d.V.; Nieddu, M.; Ennas, G.; Scano, A.; Mocci, F.; et al. Cholinium-Based Ionic Liquids from Hydroxycinnamic Acids as New Promising Bioactive Agents: A Combined Experimental and Theoretical Investigation. ACS Sustain. Chem. Eng. 2021, 9, 2975-2986. [CrossRef]

22. Pedro, S.; Freire, C.R.; Silvestre, A.; Freire, M. The Role of Ionic Liquids in the Pharmaceutical Field: An Overview of Relevant Applications. Int. J. Mol. Sci. 2020, 21, 8298. [CrossRef]

23. Tampucci, S.; Guazzelli, L.; Burgalassi, S.; Carpi, S.; Chetoni, P.; Mezzetta, A.; Nieri, P.; Polini, B.; Pomelli, C.S.; Terreni, E.; et al. pH-Responsive Nanostructures Based on Surface Active Fatty Acid-Protic Ionic Liquids for Imiquimod Delivery in Skin Cancer Topical Therapy. Pharmaceutics 2020, 12, 1078. [CrossRef]

24. Anderson, J.L.; Ding, R.; Ellern, A.; Armstrong, D.W. Structure and Properties of High Stability Geminal Dicationic Ionic Liquids. J. Am. Chem. Soc. 2005, 127, 593-604. [CrossRef] [PubMed]

25. Talebi, M.; Patil, R.A.; Armstrong, D.W. Physicochemical properties of branched-chain dicationic ionic liquids. J. Mol. Liq. 2018, 256, 247-255. [CrossRef]

26. Jin, C.-M.; Ye, C.; Phillips, B.S.; Zabinski, J.S.; Liu, X.; Liu, W.; Shreeve, J.M. Polyethylene glycol functionalized dicationic ionic liquids with alkyl or polyfluoroalkyl substituents as high temperature lubricants. J. Mater. Chem. 2006, 16, 1529-1535. [CrossRef]

27. Rizzo, C.; Marullo, S.; Dintcheva, N.T.; D’Anna, F. Carbon Nanomaterial Doped Ionic Liquid Gels for the Removal of Pharmaceutically Active Compounds from Water. Molecues 2019, 24, 2788. [CrossRef]

28. Clarke, C.J.; Morgan, P.J.; Hallett, J.P.; Licence, P. Linking the Thermal and Electronic Properties of Functional Dicationic Salts with Their Molecular Structures. ACS Sustain. Chem. Eng. 2021, 9, 6224-6234. [CrossRef]

29. Boumediene, M.; Haddad, B.; Paolone, A.; Drai, M.; Villemin, D.; Rahmouni, M.; Bresson, S.; Abbas, O. Synthesis, thermal stability, vibrational spectra and conformational studies of novel dicationic meta-xylyl linked bis-1-methylimidazolium ionic liquids. J. Mol. Struct. 2019, 1186, 68-79. [CrossRef]

30. Zullo, V.; Górecki, M.; Guazzelli, L.; Mezzetta, A.; Pescitelli, G.; Iuliano, A. Exploiting isohexide scaffolds for the preparation of chiral ionic liquids tweezers. J. Mol. Liq. 2021, 322, 114528. [CrossRef]

31. Majhi, D.; Seth, S.; Sarkar, M. Differences in the behavior of dicationic and monocationic ionic liquids as revealed by time resolved-fluorescence, NMR and fluorescence correlation spectroscopy. Phys. Chem. Chem. Phys. 2018, 20, 7844-7856. [CrossRef]

32. Ferdeghini, C.; Guazzelli, L.; Pomelli, C.S.; Ciccioli, A.; Brunetti, B.; Mezzetta, A.; Ciprioti, S.V. Synthesis, thermal behavior and kinetic study of N-morpholinium dicationic ionic liquids by thermogravimetry. J. Mol. Liq. 2021, 332, 115662. [CrossRef]

33. Kuhn, B.L.; Osmari, B.F.; Heinen, T.M.; Bonacorso, H.G.; Zanatta, N.; Nielsen, S.O.; Ranathunga, D.T.; Villetti, M.A.; Frizzo, C.P. Dicationic imidazolium-based dicarboxylate ionic liquids: Thermophysical properties and solubility. J. Mol. Liq. 2020, 308 , 112983. [CrossRef]

34. Vieira, J.C.; Villetti, M.A.; Frizzo, C.P. Thermal stability and decomposition mechanism of dicationic imidazolium-based ionic liquids with carboxylate anions. J. Mol. Liq. 2021, 330, 115618. [CrossRef]

35. Mezzetta, A.; Perillo, V.; Guazzelli, L.; Chiappe, C. Thermal behavior analysis as a valuable tool for comparing ionic liquids of different classes. J. Therm. Anal. Calorim. 2019, 138, 3335-3345. [CrossRef]

36. Shirota, H.; Mandai, T.; Fukazawa, H.; Kato, T. Comparison between Dicationic and Monocationic Ionic Liquids: Liquid Density, Thermal Properties, Surface Tension, and Shear Viscosity. J. Chem. Eng. Data 2011, 56, 2453-2459. [CrossRef]

37. Montalbán, M.G.; Víllora, G.; Licence, P. Ecotoxicity assessment of dicationic versus monocationic ionic liquids as a more environmentally friendly alternative. Ecotoxicol. Environ. Saf. 2018, 150, 129-135. [CrossRef]

38. Guglielmero, L.; Mezzetta, A.; Pomelli, C.S.; Chiappe, C.; Guazzelli, L. Evaluation of the effect of the dicationic ionic liquid structure on the cycloaddition of CO2 to epoxides. J. CO2 Util. 2019, 34, 437-445. [CrossRef]

39. Wang, W.; Zhang, Y.; Yang, Z.; Zhang, Z.; Fang, W.; Niu, D.; He, H.; Xu, F. Efficient synthesis of isosorbide-based polycarbonate with scalable dicationic ionic liquid catalysts by balancing the reactivity of the endo-OH and exo-OH. Green Chem. 2021, 23, 973-982. [CrossRef]

40. Chatterjee, K.; Pathak, A.D.; Lakma, A.; Sharma, C.S.; Sahu, K.K.; Singh, A.K. Synthesis, characterization and application of a non-flammable dicationic ionic liquid in lithium-ion battery as electrolyte additive. Sci. Rep. 2020, 10, 1-12. [CrossRef]

41. Yu, Q.; Zhang, C.; Dong, R.; Shi, Y.; Wang, Y.; Bai, Y.; Zhang, J.; Cai, M.; Zhou, F.; Liu, W. Physicochemical and tribological properties of gemini-type halogen-free dicationic ionic liquids. Friction 2021, 9, 344-355. [CrossRef]

42. Heydar, K.T.; Azadeh, A.M.; Yaghoubnejad, S.; Ghonouei, N.; Sharifi, A.; Rahnama, M.A. Characterization of a dicationic imidazolium-based ionic liquid as a gas chromatography stationary phase. J. Chromatogr. A 2017, 1511, 92-100. [CrossRef]

43. Zafer, C.; Ocakoglu, K.; Ozsoy, C.; Icli, S. Dicationic bis-imidazolium molten salts for efficient dye sensitized solar cells: Synthesis and photovoltaic properties. Electrochimica Acta 2009, 54, 5709-5714. [CrossRef]

44. Scalfani, V.F.; Al Alshaikh, A.; Bara, J.E.; Al Alshaikh, A.A. Analysis of the Frequency and Diversity of 1,3-Dialkylimidazolium Ionic Liquids Appearing in the Literature. Ind. Eng. Chem. Res. 2018, 57, 15971-15981. [CrossRef]

45. Katritzky, A.R.; Jain, R.; Lomaka, A.; Petrukhin, R.; Karelson, M.; Visser, A.A.; Rogers, R.D. Correlation of the Melting Points of Potential Ionic Liquids (Imidazolium Bromides and Benzimidazolium Bromides) Using the CODESSA Program. J. Chem. Inf. Comput. Sci. 2002, 42, 225-231. [CrossRef] 
46. Shannon, M.S.; Hindman, M.S.; Danielsen, S.; Tedstone, J.M.; Gilmore, R.D.; Bara, J.E. Properties of alkylbenzimidazoles for CO2 and SO2 capture and comparisons to ionic liquids. Sci. China Ser. B Chem. 2012, 55, 1638-1647. [CrossRef]

47. Sang, Y.; Huang, J. Benzimidazole-based hyper-cross-linked poly (ionic liquid) s for efficient CO2 capture and conversion. Chem. Eng. J. 2020, 385, 123973. [CrossRef]

48. Gupta, S.; Chatterjee, A.; Das, S.; Basu, B.; Das, B. Electrical Conductances of 1-Butyl-3-propylimidazolium Bromide and 1-Butyl3-propylbenzimidazolium Bromide in Water, Methanol, and Acetonitrile at (308, 313, and 318) K at 0.1 MPa. J. Chem. Eng. Data 2013, 58, 1-6. [CrossRef]

49. Tricoli, V.; Orsini, G.; Anselmi, M. Ion transport in a class of imidazole-based liquid/solid protic ionics. Phys. Chem. Chem. Phys. 2012, 14, 10979-10986. [CrossRef]

50. Carrillo, R.H.; Suarez-Guevara, J.; Torres-González, L.C.; Gomez-Romero, P.; Sánchez, E.M. Incorporation of benzimidazolium ionic liquid in proton exchange membranes ABPBI-H3PO4. J. Mol. Liq. 2013, 181, 115-120. [CrossRef]

51. Zhao, J.; Yan, F.; Qiu, L.; Zhang, Y.; Chen, X.; Sun, B. Benzimidazolyl functionalized ionic liquids as an additive for high performance dye-sensitized solar cells. Chem. Commun. 2011, 47, 11516-11518. [CrossRef]

52. Bains, D.; Singh, G.; Bhinder, J.; Agnihotri, P.K.; Singh, N. Ionic Liquid-Functionalized Multiwalled Carbon Nanotube-Based Hydrophobic Coatings for Robust Antibacterial Applications. ACS Appl. Bio Mater. 2020, 3, 2092-2103. [CrossRef]

53. Bansode, P.; Patil, P.; Choudhari, P.; Bhatia, M.; Birajdar, A.; Somasundaram, I.; Rashinkar, G. Anticancer activity and molecular docking studies of ferrocene tethered ionic liquids. J. Mol. Liq. 2019, 290, 111182. [CrossRef]

54. Naikwade, A.G.; Jagadale, M.B.; Kale, D.P.; Gophane, A.D.; Garadkar, K.M.; Rashinkar, G.S. Photocatalytic Degradation of Methyl Orange by Magnetically Retrievable Supported Ionic Liquid Phase Photocatalyst. ACS Omega 2020, 5, 131-144. [CrossRef]

55. Singh, A.; Raj, P.D.; Singh, A.; Dubowski, J.J.; Kaur, N.; Singh, N. Metal-Organocatalyst for Detoxification of Phosphorothioate Pesticides: Demonstration of Acetylcholine Esterase Activity. Inorg. Chem. 2019, 58, 9773-9784. [CrossRef]

56. Liang, W.; Zhang, S.; Li, H.; Zhang, G. Oxidative desulfurization of simulated gasoline catalyzed by acetic acid-based ionic liquids at room temperature. Fuel Process. Technol. 2013, 109, 27-31. [CrossRef]

57. Yuan, K.; Chen, S.; Chen, X.; Yao, S.; Wang, X.; Song, H.; Zhu, M. High effective extraction of selected anthraquinones from Polygonum multiflorum using ionic liquids with ultrasonic assistance. J. Mol. Liq. 2020, 314, 113342. [CrossRef]

58. Singh, S.K.; Dhepe, P.L. Lignin Conversion Using Catalytic Ionic Liquids: Understanding the Role of Cations, Anions, and Hammett Acidity Functions. Ind. Eng. Chem. Res. 2019, 58, 21273-21284. [CrossRef]

59. Nakamoto, H.; Noda, A.; Hayamizu, K.; Hayashi, S.; Hamaguchi, H.-O.; Watanabe, M. Proton-Conducting Properties of a Brønsted Acid-Base Ionic Liquid and Ionic Melts Consisting of Bis (trifluoromethanesulfonyl) imide and Benzimidazole for Fuel Cell Electrolytes. J. Phys. Chem. C 2007, 111, 1541-1548. [CrossRef]

60. Nakamoto, H.; Watanabe, M. Brønsted acid-base ionic liquids for fuel cell electrolytes. Chem. Commun. 2007, $2539-2541$. [CrossRef]

61. Khiratkar, A.G.; Muskawar, P.N.; Bhagat, P.R. Polymer-supported benzimidazolium based ionic liquid: An efficient and reusable Brønsted acid catalyst for Biginelli reaction. RSC Adv. 2016, 6, 105087-105093. [CrossRef]

62. Kotadia, D.A.; Soni, S.S. Silica gel supported-SO3H functionalised benzimidazolium based ionic liquid as a mild and effective catalyst for rapid synthesis of 1-amidoalkyl naphthols. J. Mol. Catal. A: Chem. 2012, 353-354, 44-49. [CrossRef]

63. Wang, Y.; Jiang, N.; Dai, L. Novel Brønsted acidic ionic liquids based on benzimidazolium cation: Synthesis and catalyzed acetalization of aromatic aldehydes with diols. Catal. Commun. 2008, 9, 2475-2480. [CrossRef]

64. Mohammadi, R.; Esmati, S.; Gholamhosseini-Nazari, M.; Teimuri-Mofrad, R. Novel ferrocene substituted benzimidazolium based ionic liquid immobilized on magnetite as an efficient nano-catalyst for the synthesis of pyran derivatives. J. Mol. Liq. 2019, 275, 523-534. [CrossRef]

65. Abbasi, M. Design, preparation and characterization of a new ionic liquid, 1,3-disulfonic acid benzimidazolium chloride, as an efficient and recyclable catalyst for the synthesis of tetrahydropyridine under solvent-free conditions. RSC Adv. 2015, 5, 67405-67411. [CrossRef]

66. Gajare, S.; Patil, A.; Kale, D.; Bansode, P.; Patil, P.; Rashinkar, G. Graphene Oxide-Supported Ionic Liquid Phase Catalyzed Synthesis of 3,4-Dihydro-2H-naphtho[2,3-e] [1,3] oxazine-5,10-diones. Catal. Lett. 2019, 150, 243-255. [CrossRef]

67. Abbasi, M. 1,3-Disulfonic acid benzimidazolium chloride as an efficient and recyclable ionic liquid catalyst for the synthesis of 3,4-dihydropyrimidine-2-(1H)-ones/thiones. Res. Chem. Intermed. 2016, 42, 3303-3314. [CrossRef]

68. Kaloglu, N.; Özdemir, I.; Gürbüz, N.; Achard, M.; Bruneau, C. Benzimidazolium sulfonate ligand precursors and application in ruthenium-catalyzed aromatic amine alkylation with alcohols. Catal. Commun. 2016, 74, 33-38. [CrossRef]

69. Majumdar, S.; De, J.; Hossain, J.; Basak, A. Formylation of amines catalysed by protic ionic liquids under solvent-free condition. Tetrahedron Lett. 2013, 54, 262-266. [CrossRef]

70. Gajare, S.; Patil, A.; Hangirgekar, S.; Dhanmane, S.; Rashinkar, G. Green synthesis of quinolines via A3-coupling by using graphene oxide-supported Brønsted acidic ionic liquid. Res. Chem. Intermed. 2020, 46, 2417-2436. [CrossRef]

71. Chen, S.-H.; Zhao, Q.; Xu, X.-W. Preparation and characterization of a novel benzimidazolium brønsted acidic ionic liquid and its application in esterifications. J. Chem. Sci. 2008, 120, 481-483. [CrossRef]

72. Khiratkar, A.G.; Balinge, K.R.; Patle, D.S.; Krishnamurthy, M.; Cheralathan, K.; Bhagat, P.R. Transesterification of castor oil using benzimidazolium based Brønsted acid ionic liquid catalyst. Fuel 2018, 231, 458-467. [CrossRef] 
73. Khiratkar, A.G.; Balinge, K.R.; Krishnamurthy, M.; Cheralathan, K.K.; Patle, D.S.; Singh, V.; Arora, S.; Bhagat, P.R. Sulphonic Acid-Functionalized Benzimidazolium Based Poly Ionic Liquid Catalyzed Esterification of Levulinic Acid. Catal. Lett. 2018, 148, 680-690. [CrossRef]

74. Zhang, M.; Zang, H.; Ma, B.; Zhang, X.; Xie, R.; Cheng, B. Green Synthesis of 5-Hydroxymethylfurfural from Chitosan Biomass Catalyzed by Benzimidazole-Based Ionic Liquids. ChemistrySelect 2017, 2, 10323-10328. [CrossRef]

75. Orazbayeva, D.; Koziel, J.A.; Trujillo-Rodríguez, M.J.; Anderson, J.L.; Kenessov, B. Polymeric ionic liquid sorbent coatings in headspace solid-phase microextraction: A green sample preparation technique for the determination of pesticides in soil. Microchem. J. 2020, 157, 104996. [CrossRef]

76. Su, H.; Wang, Q.; Wang, N.; Yang, Y. Behavior, mechanism and equilibrium studies of Au(iii) extraction with an ionic liquid [C4-6-C4BIm] Br2. Dalton Trans. 2020, 49, 504-510. [CrossRef] [PubMed]

77. Tubaro, C.; Baron, M.; Costante, M.; Basato, M.; Biffis, A.; Gennaro, A.; Isse, A.A.; Graiff, C.; Accorsi, G. Dinuclear gold(i) complexes with propylene bridged N-heterocyclic dicarbene ligands: Synthesis, structures, and trends in reactivities and properties. Dalton Trans. 2013, 42, 10952-10963. [CrossRef]

78. Hussaini, S.Y.; Haque, R.A.; Asekunowo, P.O.; Majid, A.M.S.A.; Agha, M.T.; Razali, M.R. Synthesis, characterization and antiproliferative activity of propylene linked bis-benzimidazolium salts and their respective dinuclear Silver(I)- $\mathrm{N}$-heterocyclic carbene complexes. J. Organomet. Chem. 2017, 840, 56-62. [CrossRef]

79. Al-Mohammed, N.N.; Hussen, R.S.D.; Alias, Y.; Abdullah, Z. Tris-imidazolium and benzimidazolium ionic liquids: A new class of biodegradable surfactants. RSC Adv. 2014, 5, 2869-2881. [CrossRef]

80. Al-Mohammed, N.N.; Hussen, R.S.D.; Ali, T.H.; Alias, Y.; Abdullah, Z. Tetrakis-imidazolium and benzimidazolium ionic liquids: A new class of biodegradable surfactants. RSC Adv. 2015, 5, 21865-21876. [CrossRef]

81. Küçükbay, H.; Cetinkaya, E.; Durmaz, R. Synthesis and antimicrobial activity of substituted benzimidazole, benzothiazole and imidazole derivatives. Arzneimittelforschung 1995, 45, 1131-1134.

82. Al-Mohammed, N.N.; Alias, Y.; Abdullah, Z. Bis-imidazolium and benzimidazolium based gemini-type ionic liquids structure: Synthesis and antibacterial evaluation. RSC Adv. 2015, 5, 92602-92617. [CrossRef]

83. Clark, K.D.; Nacham, O.; Yu, H.; Li, T.; Yamsek, M.M.; Ronning, D.R.; Anderson, J.L. Extraction of DNA by Magnetic Ionic Liquids: Tunable Solvents for Rapid and Selective DNA Analysis. Anal. Chem. 2015, 87, 1552-1559. [CrossRef]

84. Kar, B.; Bardhan, S.; Kundu, K.; Saha, S.K.; Paul, B.K.; Das, S. Physicochemical studies of water-in-oil nonionic microemulsion in presence of benzimidazole-based ionic liquid and probing of microenvironment using model $\mathrm{C}-\mathrm{C}$ cross coupling (Heck) reaction. RSC Adv. 2014, 4, 21000. [CrossRef]

85. Lin, Y.-R.; Chiu, C.-C.; Chiu, H.-T.; Lee, D.-S.; Lu, T.-J. Bis-benzimidazolium-palladium system catalyzed Suzuki-Miyaura coupling reaction of aryl bromides under mild conditions. Appl. Organomet. Chem. 2018, 32, e3896. [CrossRef]

86. Iwamoto, K.-I.; Kimura, H.; Oike, M.; Sato, M. Methylene-bridged bis(benzimidazolium) salt as a highly efficient catalyst for the benzoin reaction in aqueous media. Org. Biomol. Chem. 2008, 6, 912-915. [CrossRef] [PubMed]

87. Berding, J.; Lutz, M.; Spek, A.L.; Bouwman, E. Synthesis of Novel Chelating Benzimidazole-Based Carbenes and Their Nickel (II) Complexes: Activity in the Kumada Coupling Reaction. Organometallics 2009, 28, 1845-1854. [CrossRef]

88. Nozawa-Kumada, K.; Ito, S.; Noguchi, K.; Shigeno, M.; Kondo, Y. Super electron donor-mediated reductive desulfurization reactions. Chem. Commun. 2019, 55, 12968-12971. [CrossRef] [PubMed]

89. Muskawar, P.N.; Thenmozhi, K.; Gajbhiye, J.M.; Bhagat, P.R. Facile esterification of carboxylic acid using amide functionalized benzimidazolium dicationic ionic liquids. Appl. Catal. A Gen. 2014, 482, 214-220. [CrossRef]

90. Murphy, J.A.; Khan, T.A.; Zhou, S.-Z.; Thomson, D.W.; Mahesh, M. Highly Efficient Reduction of Unactivated Aryl and Alkyl Iodides by a Ground-State Neutral Organic Electron Donor. Angew. Chem. Int. Ed. 2005, 44, 1356-1360. [CrossRef]

91. Murphy, J.A.; Zhou, S.-Z.; Thomson, D.W.; Schoenebeck, F.; Mahesh, M.; Park, S.R.; Tuttle, T.; Berlouis, L.E.A. The Generation of Aryl Anions by Double Electron Transfer to Aryl Iodides from a Neutral Ground-State Organic Super-Electron Donor. Angezw. Chem. Int. Ed. 2007, 46, 5178-5183. [CrossRef] [PubMed]

92. Zhou, S.-Z.; Anderson, G.M.; Mondal, B.; Doni, E.; Ironmonger, V.; Kranz, M.; Tuttle, T.; Murphy, J.A. Organic super-electrondonors: Initiators in transition metal-free haloarene-arene coupling. Chem. Sci. 2013, 5, 476-482. [CrossRef]

93. Sword, R.; Baldwin, L.A.; Murphy, J.A. Fragmentations observed in the reactions of $\alpha$-methoxy- $\gamma$-alkoxyalkyl iodide substrates with super-electron-donors derived from 4-DMAP and N-methylbenzimidazole. Org. Biomol. Chem. 2011, 9, 3560-3570. [CrossRef] [PubMed]

94. Broggi, J.; Rollet, M.; Clément, J.; Canard, G.; Terme, T.; Gigmes, D.; Vanelle, P. Polymerization Initiated by Organic Electron Donors. Angew. Chem. Int. Ed. 2016, 55, 5994-5999. [CrossRef] [PubMed]

95. Lin, S.-T.; Ding, M.-F.; Chang, C.-W.; Lue, S.-S. Nuclear magnetic resonance spectroscopic study on ionic liquids of 1-alkyl-3methylimidazolium salts. Tetrahedron 2004, 60, 9441-9446. [CrossRef]

96. Fahlbusch, T.; Frank, M.; Schatz, J.; Schühle, D.T. Kinetic Acidity of Supramolecular Imidazolium SaltsEffects of Substituent, Preorientation, and Counterions on H/D Exchange Rates. J. Org. Chem. 2006, 71, 1688-1691. [CrossRef] [PubMed]

97. Kermanioryani, M.; Mutalib, M.I.A.; Dong, Y.; Lethesh, K.C.; Ghanem, O.B.; Kurnia, K.A.; Aminuddin, N.F.; Leveque, J.-M. Physicochemical Properties of New Imidazolium-Based Ionic Liquids Containing Aromatic Group. J. Chem. Eng. Data 2016, 61, 2020-2026. [CrossRef] 
98. Guglielmero, L.; Mezzetta, A.; Guazzelli, L.; Pomelli, C.S.; D’Andrea, F.; Chiappe, C. Systematic Synthesis and Properties Evaluation of Dicationic Ionic Liquids, and a Glance into a Potential New Field. Front. Chem. 2018, 6, 612. [CrossRef]

99. Cao, Y.; Mu, T. Comprehensive Investigation on the Thermal Stability of 66 Ionic Liquids by Thermogravimetric Analysis. Ind. Eng. Chem. Res. 2014, 53, 8651-8664. [CrossRef]

100. Gómez, E.; Calvar, N.; Domínguez, Á.; Macedo, E.A. Thermal behavior and heat capacities of pyrrolidinium-based ionic liquids by DSC. Fluid Phase Equilibria 2018, 470, 51-59. [CrossRef]

101. Ramos, J.J.M.; Afonso, C.A.M.; Branco, L.C. Glass transition relaxation and fragility in two room temperature ionic liquids. J. Therm. Anal. Calorim. 2003, 71, 659-666. [CrossRef]

102. Sippel, P.; Lunkenheimer, P.; Krohns, S.; Thoms, E.; Loidl, A. Importance of liquid fragility for energy applications of ionic liquids. Sci. Rep. 2015, 5, 13922. [CrossRef]

103. Gómez, E.; Calvar, N.; Domínguez, Á.; Macedo, E.A. Thermal Analysis and Heat Capacities of 1-Alkyl-3-methylimidazolium Ionic Liquids with NTf2-, TFO-, and DCA- Anions. Ind. Eng. Chem. Res. 2013, 52, 2103-2110. [CrossRef]

104. Ogawa, K.A.; Boydston, A.J. Electrochemical Characterization of Azolium Salts. Chem. Lett. 2014, 43, 907-909. [CrossRef]

105. Rocco, D.; Chiarotto, I.; D’Anna, F.; Mattiello, L.; Pandolfi, F.; Rizzo, C.; Feroci, M. Cathodic Behaviour of Dicationic Imidazolium Bromides: The Role of the Spacer. ChemElectroChem 2019, 6, 4275-4283. [CrossRef]

106. Kazemiabnavi, S.; Zhang, Z.; Thornton, K.; Banerjee, S. Electrochemical Stability Window of Imidazolium-Based Ionic Liquids as Electrolytes for Lithium Batteries. J. Phys. Chem. B 2016, 120, 5691-5702. [CrossRef] [PubMed]

107. Riederer, S.K.U.; Gigler, P.; Hogerl, M.P.; Herdtweck, E.; Bechlars, B.; Herrmann, W.A.; Kuhn, F.E. Impact of Ligand Modification on Structures and Catalytic Activities of Chelating Bis-Carbene Rhodium(I) Complexes. Organometallics 2010, 29, 5681-5692. [CrossRef] 